\title{
The Teggiolo zone: a key to the Helvetic-Penninic connection (stratigraphy and tectonics in the Val Bavona, Ticino, Central Alps)
}

\author{
Battista Matasci · Jean-Luc Epard • \\ Henri Masson
}

Received: 19 July 2010/Accepted: 11 March 2011/Published online: 19 August 2011

(C) Swiss Geological Society 2011

\begin{abstract}
The Teggiolo zone is the sedimentary cover of the Antigorio nappe, one of the lowest tectonic units of the Penninic Central Alps. Detailed mapping, stratigraphic and structural analyses, and comparisons with less metamorphic series in several well-studied domains of the Alps, provide a new stratigraphic interpretation. The Teggiolo zone is comprised of several sedimentary cycles, separated by erosive surfaces and large stratigraphic gaps, which cover the time span from Triassic to Eocene. At MidJurassic times it appears as an uplifted, partially emergent block, marking the southern limit of the main Helvetic basin (the Limiting South-Helvetic Rise LSHR). The main mass of the Teggiolo calcschists, whose base truncates the Triassic-Jurassic cycles and can erode the Antigorio basement, consists of fine-grained clastic sediments analogous to the deep-water flyschoid deposits of Late Cretaceous to Eocene age in the North-Penninic (or Valais s.l.) basins. Thus the Antigorio-Teggiolo domain occupies a crucial paleogeographic position, on the boundary between the Helvetic and Penninic realms: from Triassic to Early Cretaceous its affinity is with the Helvetic; at the end of Cretaceous it is incorporated into the North-Penninic basins. An unexpected result is the discovery of the important role played by complex formations of wildflysch type at the top of the Teggiolo zone. They contain blocks of various sizes. According to their nature, three different associations are distinguished that have specific vertical and lateral distributions. These blocks give clues to the
\end{abstract}

Editorial handling: A.G. Milnes.

B. Matasci · J.-L. Epard $(\bowtie) \cdot$ H. Masson

Institut de Géologie et Paléontologie, Anthropole,

Université de Lausanne, 1015 Lausanne, Switzerland

e-mail: Jean-Luc.Epard@unil.ch existence of territories that have disappeared from the present-day level of observation and impose constraints on the kinematics of early folding and embryonic nappe emplacement. Tectonics produced several phases of superimposed folds and schistosities, more in the metasediments than in the gneissic basement. Older deformations that predate the amplification of the frontal hinge of the nappe generated the dominant schistosity and the km-wide Vanzèla isoclinal fold.

Keywords Antigorio - Lepontine - Penninic - Helvetic . Wildflysch · Superimposed folds

\section{Introduction}

This work aims at a better understanding of stratigraphy and tectonics in the highly metamorphic rocks of the Lepontine Alps, especially in the Val Bavona, western Ticino (Fig. 1). This complex part of the Alpine belt has already been the subject of numerous studies. Based on classical stratigraphy and mapping (e.g. Schmidt 1907; Schmidt and Preiswerk 1908a, b; Burckhardt 1942; Günthert 1954, 1958; Burckhardt and Günthert 1957), a number of more modern publications have brought pioneering contributions to the study of its structure and kinematics (e.g. Milnes 1974; Huber et al. 1980; Huber 1981; Steck 1984, 2008; Greco 1985; Leu 1986; Steck and Hunziker 1994; Grujic and Mancktelow 1996; Maxelon and Mancktelow 2005). The reader will find good introductions to the regional geology of the Lepontine Alps in these last publications and in the explanatory notes of the tectonic maps of Steck et al. (2001) and Berger et al. (2007).

The recent discovery and stratigraphic analysis of reliable marker horizons leads to an entirely new stratigraphic 
Fig. 1 Geological map of the Val Bavona region (NW Ticino). AA': geological crosssection through the area of detailed study, shown on Fig. 10. Modified from Steck et al. (1999) and Berger and Mercolli (2006)

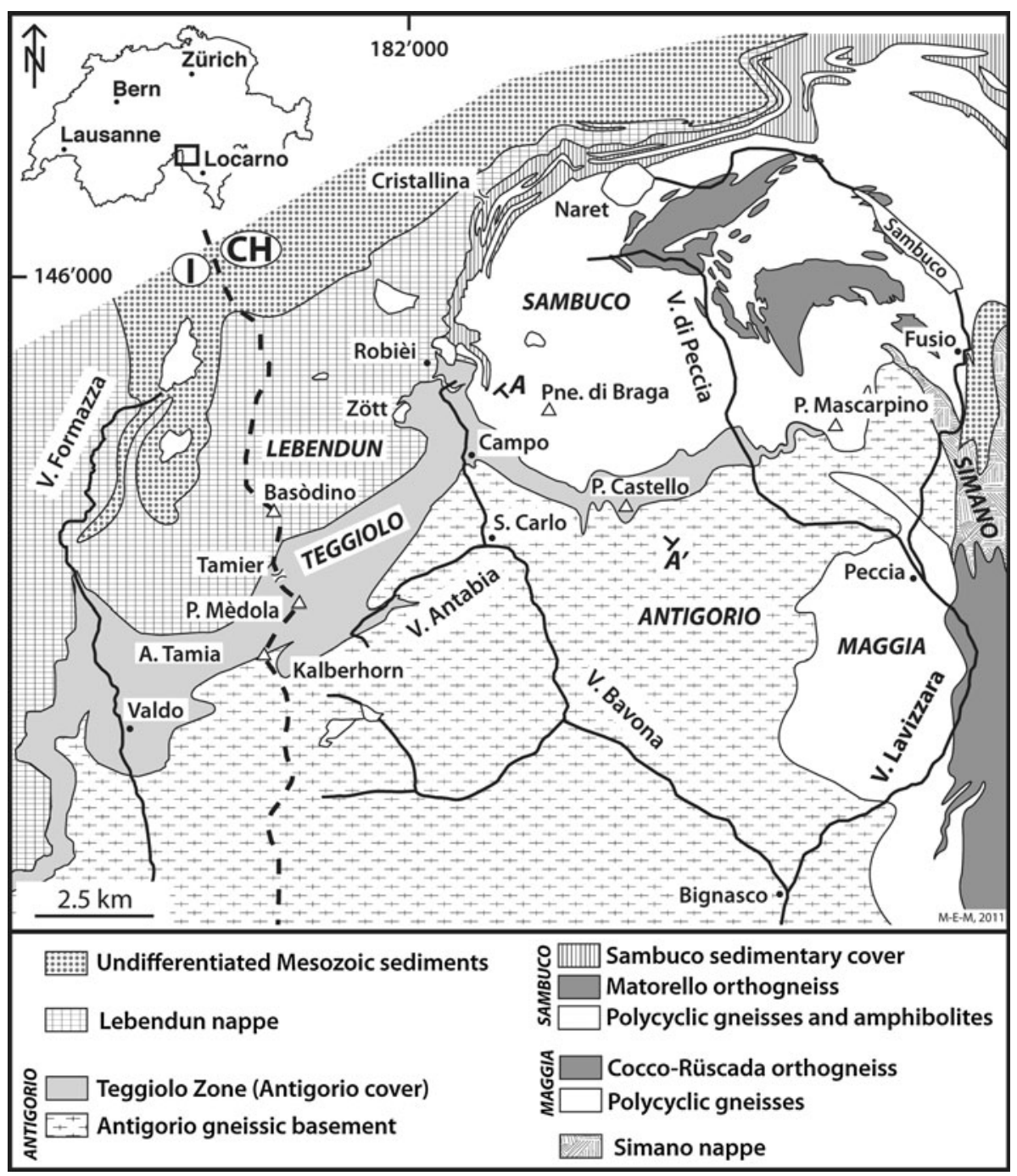

framework with important tectonic and paleogeographic consequences. Here we will focus on a thick band of metasedimentary rocks called the Teggiolo zone that can be followed over $50 \mathrm{~km}$ from the Val Divedro (Simplon-Domodossola transect) to the higher Val Maggia (Ticino). Our study is based on detailed mapping, stratigraphy and structural analysis of this zone on the eastern bank of $\mathrm{Val}$ Bavona between Robièi and the Pizzo Castello (Fig. 1). We will also refer more briefly to results obtained by the same methods in the Val Antabia, on the western bank of Val Bavona, by Carreras and Jequier (2002) and one of us (H.M.).

\section{Problems of the Teggiolo zone: the classical and the new framework}

The Teggiolo zone is the sedimentary cover of the Antigorio gneissic basement. Both together form the Antigorio nappe, which is one of the lowest tectonic units in the Penninic domain of the Central Alps (number I in Argand's classical tectonic synthesis; Argand 1911; Escher et al. 1993; Steck et al. 2001; Steck 2008).

We will first summarize the standard interpretations, the controversies, and the main features of the new stratigraphic and tectonic framework that will be developed in the following pages:

1. The Teggiolo zone was originally defined by Schmidt (1907) and Schmidt and Preiswerk (1908b) as a several hundred $\mathrm{m}$ thick band of Mesozoic metasediments separating the Antigorio gneiss from the overlying Lebendun gneiss. It can be followed in this position for $40 \mathrm{~km}$ from the Simplon-Domodossola transect to Robièi in the Val Bavona.

2. Schmidt and Preiswerk (1908b) considered both the Antigorio and Lebendun gneisses as Paleozoic. This still is the dominant opinion in the recent literature. However, if the Variscan age of the Antigorio 
orthogneiss is well documented (289-296 Ma, Bergomi et al. 2007), work in progress confirms the suggestions (Rodgers and Bearth 1960; Spring et al. 1992; Canepa 1993) of a post-Triassic age of the Lebendun paragneiss. However, this controversy does not affect the definition of the Teggiolo zone because the basal contact of the Lebendun gneiss upon the Teggiolo metasediments is always a thrust.

3. The Teggiolo zone mainly consists of calcitic and dolomitic marbles and for the larger part of calcschists (in general meta-siltstones to meta-sandstones, with transitions towards quartzites, micaschists, etc.; these calcschists are also traditionally called Bündnerschiefer). At the time of Schmidt and Preiswerk (1908a, b) all the marbles were considered as Triassic, and the Bündnerschiefer as Jurassic. Today these conventional attributions still form the standard stratigraphic framework (e.g. Günthert 1954, 1958; Burckhardt and Günthert 1957; Greco 1985; Leu 1986). However, we will show that with modern knowledge of Alpine stratigraphy they are no more tenable: only the dolomites can be Triassic. The limestones (calcitic marbles) must be Late Jurassic, and the Teggiolo calcschists Cretaceous to Tertiary.

4. As a logical consequence of their stratigraphic interpretation, Schmidt and Preiswerk (1908b) considered the Teggiolo zone to represent a syncline (the "Teggiolo Mulde"). Today a synclinal axial trace in the middle of this zone is still an important element of several modern tectonic interpretations. We will show that this is not the case: the present work demonstrates that the Teggiolo zone is formed by an essentially normal stratigraphic series whose top is overlain by the thrusts either of the Lebendun or of the Sambuco nappe. Consequently it is not a fold and the "Teggiolo syncline" disappears.

5. The definition of the Teggiolo zone given above breaks in the Val Bavona at Robièi, because of the sudden intercalation of another nappe with a thick Paleozoic gneissic core between the Antigorio and Lebendun units: the Sambuco nappe (formerly considered to be the northern part of the Maggia nappe; we adopt the terminology introduced by Berger et al. 2007). Thus, at the Robiei triple point, the Bündnerschiefer form a star with three branches (Fig. 1): (a) one branch runs SW towards Italy between the Antigorio and Lebendun gneisses: it is by definition the classical Teggiolo zone; (b) a second branch runs towards $\mathrm{N}$ then NE through the Cristallina pass and the northern shore of the Naret lake, between the Sambuco and Lebendun gneisses; several authors saw in it a continuation of the Teggiolo zone, that would eventually merge with the so-called Bedretto zone; work in progress completely excludes this interpretation in revealing that this northern branch entirely belongs to the sedimentary cover of the Sambuco nappe, whose stratigraphic column is distinct from the Teggiolo zone (Délèze 1999; Lodetti 2001; Steck et al. 1999, 2001); (c) the third branch runs eastwards on the eastern bank of the Bavona, between the Antigorio and Sambuco gneisses: its stratigraphic content is identical to that of the first branch and it is the true continuation of the Teggiolo zone. Its study is the subject of the present work. From Robièi it can be followed to the SE for nearly $10 \mathrm{~km}$ up to the foot of the Pizzo Mascarpino, where it disappears in enigmatic conditions (Fig. 1; see below Sect. 5.2).

6. Consequently the Teggiolo zone is overthrusted on the western bank of the Bavona by the Lebendun nappe and on its eastern bank by the Sambuco nappe. Our work shows that the sedimentary cover of the latter, which is well developed in the Naret and Cristallina areas, thins out towards S and disappears at Robièi: SE of this locality, the Sambuco gneissic basement directly overlies the Teggiolo zone (Figs. 1,2). Thus the metasediments pinched between the Antigorio and Sambuco basements entirely belong to the Antigorio nappe. At Robiei the three nappes are folded together in a complex way that is the subject of research in progress.

These points and their consequences will now be developed in detail.

\section{Stratigraphy}

\subsection{Methodology}

No fossils are known in these highly metamorphic rocks. However, a stratigraphic framework can be established by classical sedimento-structural criteria (discordances, reworking, etc.) and by comparisons with less metamorphic series in several well-studied paleogeographic domains of the Alps.

Intensity of deformation is very variable in both the granite and its Mesozoic cover. At places strain is astonishingly moderate and sedimentary structures in the cover (or intrusive relationships in the basement) are well recognizable. This point has already been emphasized by Milnes $(1964,1965)$ on the Monte Cistella (15 km NNW Domodossola, Italy), where weak Alpine overprinting ensures a good preservation of original stratigraphic features along the cover/basement contact. These favorable circumstances make it possible to establish in the Teggiolo zone the existence of several sedimentary cycles, separated by erosive surfaces that are discordant at the map scale 
Fig. 2 Synthetic stratigraphic sections of the Teggiolo zone in the Val Bavona. The sedimentary cycles distinguished in the text are as follows: first cycle, Dolomite (Triassic); second cycle, Ri d'Antabia conglomerate, Sevinèra sandstone, Sevinèra marble, Vanis banded marble (Jurassic-Early Cretaceous); third cycle, Piano delle Creste sandstone, Mèdola quartzite (Late Cretaceous-Tertiary); fourth cycle, Robièi wildflysch (Tertiary)

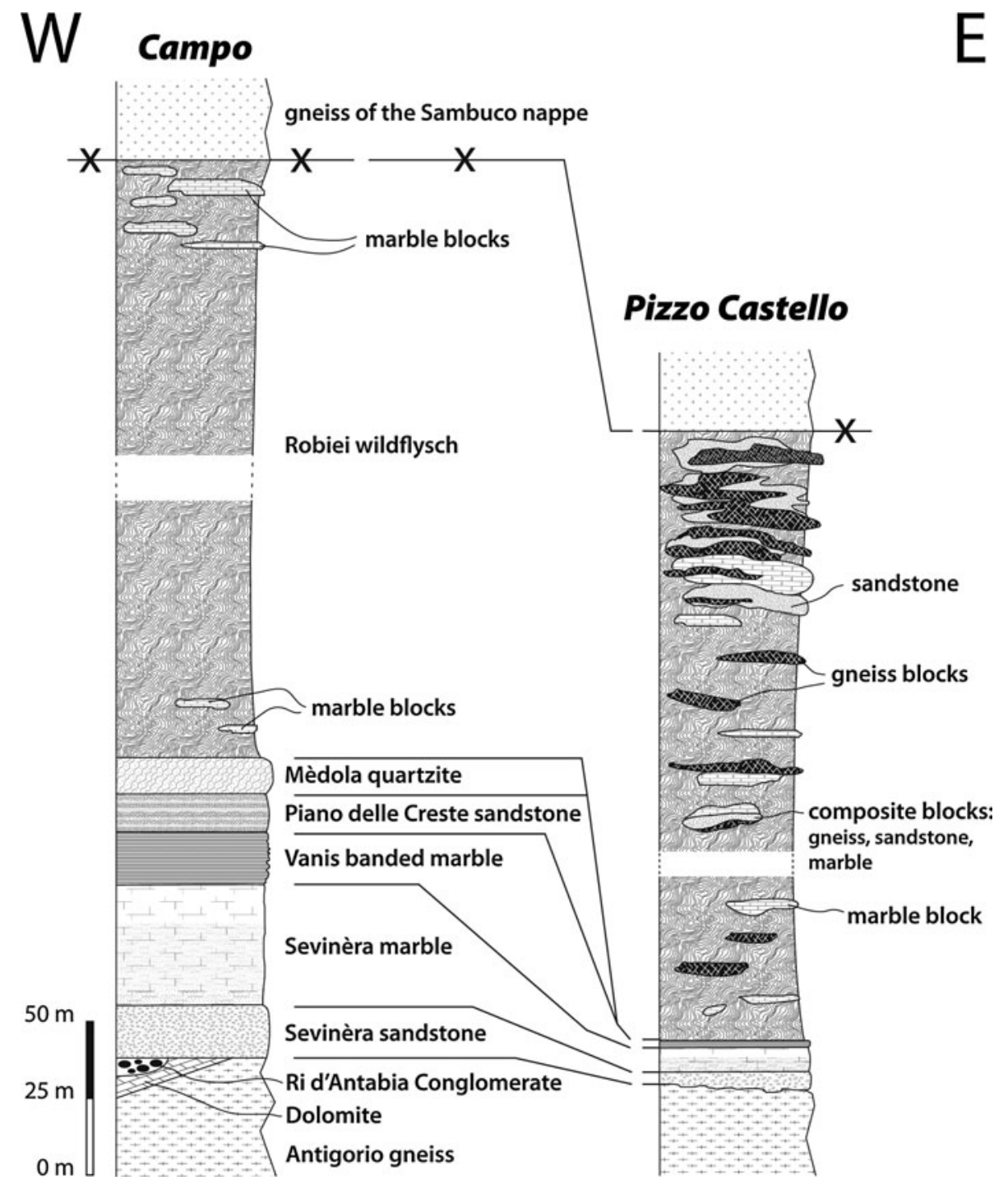

(Fig. 2). However, at several places large scale superimposed folding (e.g. the Vanzèla fold, see below Sect. 4.6) makes very detailed mapping absolutely necessary for deciphering stratigraphy.

\subsection{First sedimentary cycle: the Triassic}

Where the stratigraphic column is the most complete, it starts with the Triassic. In the survey area (left bank of Val Bavona), the Triassic is only preserved at Campo, where it crops out immediately $\mathrm{E}$ of the hamlet (683.350/141.930) and $150 \mathrm{~m} \mathrm{~S}$ of the bridge in the bed of the Bavona river. Elsewhere it has been eroded below the Jurassic transgression.

The Triassic is mainly made of dolomite. At Campo the first $\mathrm{m}$ of this dolomitic formation consist of an alternation of cm-thick beds of pure dolomite, micaceous dolomite, dolomitic micaschist (sometimes with tremolite and calcite), carbonate-free micaschist and micaceous quartzite. Their protolith must have been an alternation of dolomite and fine-grained detrital sediments containing variable amounts of quartz, clay minerals and dolomite. The transition of this alternation to the overlying massive dolomite seems gradual.

Elsewhere in the Teggiolo zone, the base of the Triassic can be made of a m-thick layer of quartzite surmounted by a whitish garnet-staurolite-kyanite micaschist (Al-rich metapelite), e.g. on the Teggiolo mountain (Schmidt and Preiswerk 1908b, p. 20; Spring et al. 1992, their crosssection C). The Teggiolo Triassic may also contain thick intercalations of anhydrite such as those encountered in the Simplon tunnel in the overturned limb of the Antigorio nappe (Schardt 1903).

The age of this dolomitic formation is obviously Triassic, as accepted by all authors. Comparison with various Triassic sequences in the Western and Central Alps shows 
similarities with the Triassic of the Helvetic sensu lato domain (e.g. Frey 1968; Mégard-Galli and Baud 1977; Epard 1989; Gisler et al. 2007). It has no affinity with the Briançonnais Triassic. This point is noteworthy in view of the recent discovery of Briançonnais Triassic formations in completely unexpected localities of the Central Alps (Galster et al. 2010).

\subsection{Second sedimentary cycle: the Antabia group (Jurassic-Early Cretaceous)}

\subsubsection{Introduction}

The second sedimentary cycle is comprised of a coarsegrained detrital series passing upwards to a limestone formation. In spite of the existence of transitional rock types, sharp limits with a wide lateral extent permit the definition in this sequence of several lithostratigraphic units that are mappable at a regional scale and therefore can be considered as formations. The base of the sequence is always erosive. In most of the studied area and in many other parts of the Antigorio nappe, this erosion completely destroyed the Triassic. Then the conglomerates or sandstones that form the lower part of this sequence lie directly on the Paleozoic basement. Farther SW, in the Val Antabia and in Italy, this sequence is in turn truncated by the base of the main mass of the calcschists.

\subsubsection{The Ri d'Antabia conglomerate}

The second sedimentary cycle starts sporadically with a coarse conglomerate. It is best developed at the cascade of the Ri d'Antabia (2.5 km SW San Carlo; 681.4/138.8) where it reaches a thickness of $20 \mathrm{~m}$. There it consists of several $\mathrm{m}$-thick layers of variable composition that represent distinct successive detrital events, with rapid lateral variations. In broad lines they show an inverse reconstitution of the eroded series: the first layers contain mixed calcareous and dolomitic pebbles; the source of the dolomitic clasts is obviously Triassic, while the limestones, that are unknown in the underlying stratigraphic column, presumably originate from the erosion of a post-Triassic and pre-conglomeratic, completely destroyed part of the column. Some layers show a weak graded-bedding with an increasing upwards proportion of sandy matrix. It also contains a layer of biotite-rich micaschist that might represent a metapelitic intercalation. Gneissic elements appear higher up, first as rare clasts dispersed in the mainly calcodolomitic conglomerate. The top of the conglomerate is formed by a $4 \mathrm{~m}$ thick layer entirely made of gneissic pebbles in an abundant arkosic matrix. At first sight this gneissic conglomerate might look like a genuine gneiss and has indeed been mapped as a tectonic slice of basement by Burckhardt and Günthert (1957) and by Huber (1981).

The Ri d'Antabia conglomerate extends to Campo where it is exposed in the bed of the Bavona river. Here it rests upon the lower layers of the Triassic dolomite. It consists in an often purely dolomitic, monomict conglomerate or breccia that, at first sight, could easily be confused with genuine Triassic dolomite. However, the clastic structure is often well recognizable. At several places it also contains a few pebbles of gneiss. It clearly represents a basal conglomerate, transgressive on the partially eroded Triassic dolomite that it reworks with a smaller amount of elements eroded from the granitic basement. Above Campo a conglomerate has been mapped by Schmidt and Preiswerk (1908a) but is no longer visible today. It never reappears (nor the Triassic) farther $E$ on the left bank of Val Bavona, where the Sevinèra sandstone (see below) is always transgressive on the Antigorio gneiss.

Other conglomerates occur in a similar position at several places along the base of the Teggiolo zone in Italy. Good examples are found at the NW foot of the Teggiolo mountain where they have already been noted by Schmidt and Preiswerk (1908a) and by Spring et al. (1992, their cross-section D). At the base of the slope (near Véina), in the inverse limb of the nappe, a very demonstrative and easily accessible outcrop shows a conglomerate formed of well rounded boulders of Antigorio granite, occasionally accompanied by pebbles of marble and quartzite, filling an (overturned) small depression eroded into the gneiss. Following the contact uphill towards the hinge of the nappe, several other channels of decametric width and 5-10 m depth occur at the top the gneiss and are filled by mainly gneissic conglomerates. They pass upwards to the sandstones and marbles that usually form the base of the Teggiolo zone in this area. On the other side of the valley, on Monte Cistella, Milnes (1964) observed similar conglomerates at the base of the metasediments. They contain aplitic and granitic pebbles and blocks, identical to the underlying Antigorio granite.

Although sporadic, these conglomerates are of prime importance for the interpretation of the Teggiolo zone: (1) for stratigraphy: as they can in no case be Triassic (see below Sect. 3.3.6), they prove the post-Triassic age of the rest of the series (including the overlying marbles, generally considered as Triassic); (2) for tectonics: they are like pins that fix the Teggiolo sedimentary cover on the Antigorio gneiss. At Antabia, the confusion of the gneissic conglomerate with a basement slice gave rise to suggestions of intense shearing at the base of the Teggiolo zone. Just on the contrary the conglomerates demonstrate the autochtony of the sedimentary cover with respect to its gneissic basement. 


\subsubsection{The Sevinèra sandstone}

The post-Triassic sequence usually starts with a decameterthick layer of calcareous sandstone. At the Antabia waterfall it rests with a sharp limit upon the conglomerate described above. For this reason, even if the base of the sandstone is itself slightly conglomeratic, we prefer to consider it as a distinct formation. It is well exposed not only at Antabia but also on the eastern bank of Val Bavona, e.g. at the Alpe di Sevinèra (elevation about 2,100 m, E of Campo; from 684.2/141.7 to 685.0/141.5). Therefore, we name this formation the Sevinèra sandstone. In the classical literature (e.g. Burckhardt 1942; Burckhardt and Günthert 1957; Huber 1981) it was incorporated into the "Triassic marble"; however, it is a true sandstone and is surmounted with a sharp contact by the marbles of the next formation. On the left bank of Val Bavona E of Campo, where the Triassic is absent, the Sevinèra sandstone always lies directly on the gneissic basement.

The Sevinèra sandstone typically is coarse-grained and contains about 30-50\% quartz, 20-40\% calcite and 20-35\% feldspar. Some variations can be observed in the proportions of these minerals, locally causing a thin bedding of this sandstone that usually looks rather homogenous and massive. Rare, extreme cases are decimetric layers of a weakly calcareous quartzite or of a quartzic calcarenite (at its base in the Vanis ravine above Campo).

The base of the sandstone is often (but not always) conglomeratic, on a thickness that can reach $1 \mathrm{~m}$, with centimetric to decimetric, sometimes well-rounded pebbles of gneiss or quartzite dispersed in the sandy matrix. Usually their abundance and size decrease gradually upwards. The source of the gneissic pebbles seems to be the underlying Antigorio gneiss, while the source of the quartzitic pebbles seems compatible with the quartzite layer that sometimes forms the base of the Triassic (see above). At several places one observes infiltrations of the sandstone into the underlying gneiss and a kind of progressive transformation of the gneiss into arkosic sandstone immediately below the calcareous sandstone. These features strongly suggest that the Sevinèra formation transgressed on a weathered basement. They have been already described by Burckhardt (1942, p. 166-169) who gave a correct interpretation. On the contrary Reinhard and Preiswerk (1934) and Huber (1981, p. 124-130) proposed a tectonic interpretation of the same features and spoke of "tektonische Brekzienbildung" and "Pseudokonglomerat" generated by a strong shearing along the contact. According to our observations these structures definitely have a sedimentary origin and prove once more the strict autochtony of the Teggiolo zone upon the Antigorio basement. The base of the Sevinèra sandstone displays typical characteristics of a stratigraphic contact, and neither the sandstone nor the immediately underlying gneiss show any sign of a stronger tectonization than the rest of the nappe.

\subsubsection{The Sevinèra marble}

Calcitic marbles are a conspicuous constituent of the Teggiolo zone, although their distribution is discontinuous because they frequently disappear by erosion below the base of the third sedimentary cycle. They are well exposed on both banks of Val Bavona where their thickness can reach $30 \mathrm{~m}$. Their lower limit with the Sevinèra sandstone is sharp. As they make nice outcrops at the same locality we call this marble formation the Sevinèra marble. It shows a gradual vertical evolution in composition and aspect and can conveniently be subdivided into two members:

1. The lower part has a characteristic yellowish to brownish color ("yellow member"). The base of this member is banded and consists in an alternation of cmor dm-thick beds of slightly impure limestones (10-20\% of fine-grained quartz, feldspar, mica and dolomite), with more impure and more coarsely quartzic and micaceous limestones or calcschists (Fig. 3). It passes very progressively upwards, by attenuation of the bedding and increasing purity, to a more homogenous and massive, still yellowish limestone. The protolith of this sequence must have been an alternation of beds of more or less argillaceous limestones and marls, with decreasing upwards content in clay minerals and other fine-grained detritals.

2. The upper part is a very pure limestone ( $98 \%$ calcite). It is massive, homogeneous and white ("white member").

\subsubsection{The Vanis banded formation}

A very characteristic, $10-15 \mathrm{~m}$ thick, banded formation overlies the white marble with a sharp contact. It consists in an alternation of centimeter- to decimeter-thick beds of light-colored, often slightly orange, impure marble, with dark calcschists of variable thickness. The well marked layering of these two rocks with contrasted rheological properties is favorable to folding (Fig. 11).

This banded marble/calcschist association occurs very continuously above the Sevinèra marble, as well in the Val Antabia as near Campo or farther E through the Alpe di Sevinèra up to the foot of the Pizzo Castello. As it is well exposed in the northern cliff of the Vanis ravine above Campo (e.g. 683.650/142.050) we name it the Vanis Formation. 


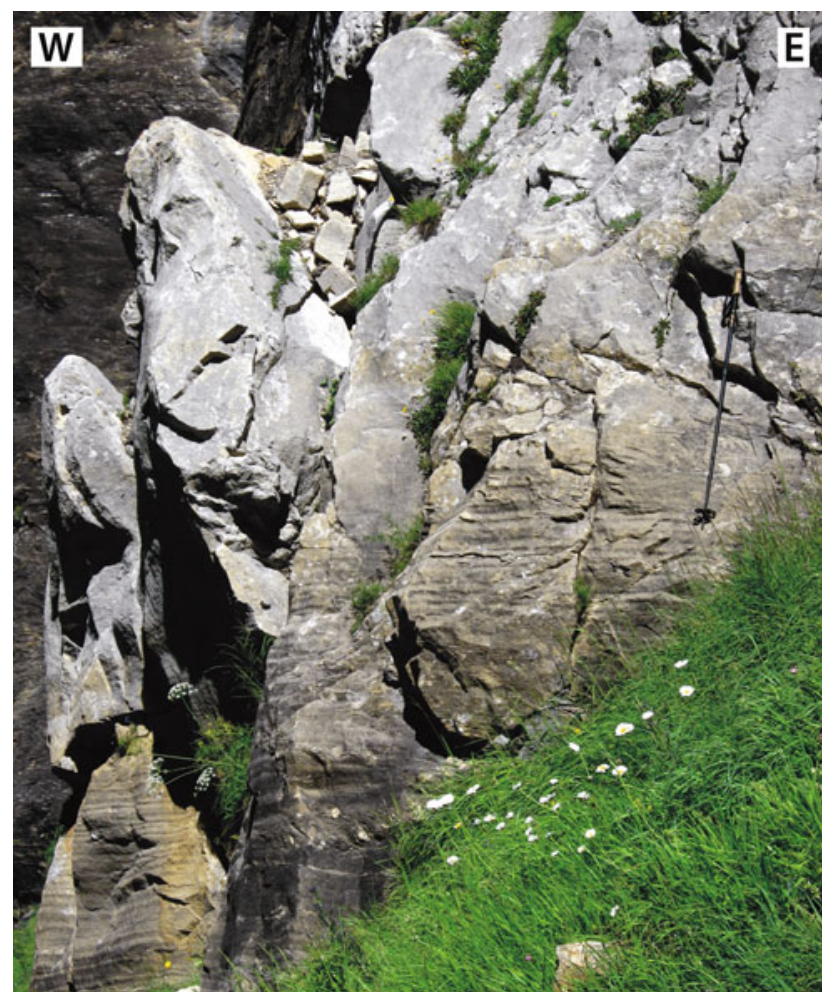

Fig. 3 The Sevinèra marble: gradual transition from the lower, banded "yellow" member to the upper, massive "white" member (ski-stick for scale, ca. $120 \mathrm{~cm}$ ). Vanis ravine, ENE Campo (coord. $683.72 / 142.03)$

\subsubsection{Age and stratigraphic interpretation of the Antabia group}

We have defined in the Teggiolo zone four distinct stratigraphic units above the Triassic dolomite. They are from bottom upwards: (1) the Ri d'Antabia conglomerate (sporadic); (2) the Sevinèra sandstone; (3) the Sevinèra marble; and (4) the Vanis banded marble/calcschist. They are all separated by sharp limits, are easily mappable and have a regional extent (with the exception of the conglomerate, which is discontinuous but nevertheless forms a mappable unit). Consequently they are conveniently treated as lithostratigraphic formations. It is useful to define this whole set of formations as a lithostratigraphic group that we call the Antabia group, because the most complete cross-section is exposed in the Val Antabia where we also observe its truncation by the base of the next sedimentary cycle. The basal contact of this group on the Paleozoic gneiss or the Triassic dolomite is definitely stratigraphic and erosive, as described above, and the immediately underlying rocks never show any hint of unusual tectonization.

In the classical literature the Antabia group is simply called "marble" and is ascribed to the Triassic. In the light of modern Alpine stratigraphy, this age can be absolutely excluded for at least three reasons: (1) At several places the Ri d'Antabia conglomerate erodes and reworks the Triassic dolomite. (2) More generally, the conglomerate and the Sevinèra sandstone have no place in the Triassic paleogeography of the Central and Western Alps (see MégardGalli and Baud 1977); and ascribing these rocks to the Triassic would imply a complete change of the paleogeographic and geodynamic reconstructions. (3) The main reason for the Triassic attribution seems to be a tentative correlation of the marbles with the thick limestone layers of the Triassic Briançonnais province. However, the Briançonnais Triassic limestones have very specific lithological characteristics (Baud and Mégard-Galli 1975; Baud 1987) that do not correspond at all to the Sevinèra marbles.

The best candidate for a stratigraphic correlation with the Sevinèra marble is the Malm (Late Jurassic), more especially the Malm limestones of the Helvetic s.l. domain. The similarity is indeed striking between the lithological vertical evolution of the Sevinèra marble and the Helvetic Malm sequence which starts with alternating beds of marls and marly limestones of Oxfordian age (e.g. the Schilt Formation, often improperly called "Argovian" in the classical literature) and passes gradually upwards to pure limestones of Kimmeridgian and Tithonian age (Quinten Formation; e.g. Anatra 1986; Kugler 1987).

If the Sevinèra marble is Late Jurassic, then the Sevinèra sandstone and the sporadic conglomerates must have an Early or more probably Middle Jurassic (Dogger) age. Comparison with the Helvetic domain provides again valuable clues. The rises or paleogeographic threshholds that border or separate the Helvetic Dogger basins typically present relatively thin detrital series of this age (sandstones and calcarenites, sometimes with a basal conglomerate) transgressive on eroded Liassic, Triassic or even Paleozoic basement (e.g. Masson et al. 1980). For instance the Antabia section shows remarkable analogies with the sedimentary cover of the Internal Mont-Blanc massif in the higher Val Ferret, whose base is a conglomerate formed of granitic boulders transgressive on the Mont-Blanc granite, followed by sandstones and calcarenites of Dogger age, then by the classical Malm sequence (Grasmück 1961). Analogies also exist with sections in the sedimentary cover of the Aar massif (Bugnon 1986). Of course the Teggiolo zone cannot correspond paleogeographically to the Internal Mont-Blanc-Aar rise (which stands at the northern border of the main Helvetic basin). But these analogies strongly suggest that, more or less symmetrically, an Antigorio (or Teggiolo) rise formed the southern border of the Helvetic basin and was submitted during Jurassic times to a similar evolution. These considerations will be developed below (see Sects. 5.1 and 5.3).

In the Helvetic domain, the Malm limestone is always overlain by an alternation of beds of marls and more or less 
impure limestones of earliest Cretaceous age (Berriasian), often with a sharp contact. In the Ultrahelvetic nappes, whose origin is nearest to the Lower Penninic, this lithology extends to most of the Lower Cretaceous (Anatra 1986; Busnardo et al. 2003). This lithology fits well with the protolith of the Vanis banded marble/calcschist formation. Consequently we propose an Early Cretaceous (Berriasian and maybe partly younger) age for the Vanis formation. This extends to the Early Cretaceous the analogy of the Teggiolo zone with the inter-basinal rises of the Helvetic s.l. realm.

\subsection{Third sedimentary cycle: lower part of the Teggiolo calcschists (Late Cretaceous-Tertiary)}

\subsubsection{Introduction}

Above the Antabia group comes the main mass of the Teggiolo calcschists or Bündnerschiefer. It can be subdivided into two parts: (1) A lower part is made of regular, well-stratified lithostratigraphic units. In the Val Antabia its base truncates the two preceding cycles and reaches the Antigorio basement. This basal discontinuity is interpreted as a major stratigraphic gap. (2) An upper part is more disordered, sometimes even chaotic, and contains blocks of exotic rocks. We will demonstrate that it is a wildflysch (cf. Sects. 3.5 and 5.2). Its base is itself discordant and truncates the lower part on the left bank of the Bavona river above Campo at an elevation of about 2,100 m, unfortunately in bad outcrop conditions (approximately 684.300/141.750). The lower part of the Bündnerschiefer definitively disappears here and farther E (e.g. at the Alpe di Sevinèra or around the $\mathrm{P}$. Castello) the wildflysch always lies directly on the Antabia group. For these reasons we will consider that the lower part forms a sedimentary cycle of its own (the third one) and the upper part belongs to a fourth cycle. Another unconformity probably also exists inside the lower part of the calcschists, but this point is not yet completely clear and will be discussed below.

The third cycle is best developed in the Val Antabia where it is clearly subdivided into three well distinct, easily mappable, decameter- to hectometer-thick lithostratigraphic units that are conveniently considered as formations (Carreras and Jequier 2002). We give a short description.

\subsubsection{The Piano delle Creste sandstone}

Named after the Piano delle Creste rifugio in the Val Antabia, this formation is made of sandstone layers of variable thickness, grain size and composition. It often consists of decimeter-thick beds of more or less quartzitic sandstones alternating with more calcareous sandstones (up to $30 \%$ calcite, with small amounts of feldspar and mica). Composition and aspect are rather heterogeneous but these sandstones are always well bedded.

\subsubsection{The Pianasciom calcschist}

This formation is characterized by thick layers of calcschists rich in large blasts of plagioclase that give them a very typical "bumpy" appearance. Its basal contact with the Piano delle Creste sandstone is transitional. Thinner layers of various sandstones and more rarely of limestones are intercalated. Near the top it can also contain intercalations of micaschists with blasts of plagioclase, garnet and locally amphibole. The mineralogy of these rocks has been studied in detail by Allaz (2008) who calculated peak metamorphic conditions around $\mathrm{T}=570^{\circ} \mathrm{C}$ and $\mathrm{P}=7 \mathrm{~kb}$, presumably 20-22 Ma ago.

This formation forms large outcrops on the Pianasciom shelf in Val Antabia that we choose as type locality. It becomes much thinner at Campo and for this reason has been omitted on Figs. 2 and 10. It also seems to vanish on the Italian side of the Kalberhorn (pt. 2805 on the boundary crest).

\subsubsection{The Mèdola quartzite}

This is also a very characteristic lithology, well exposed at the Pizzo Mèdola (pt 2957 on the Swiss-Italian border; 678.620/137.730), where it is overthickened by folding (see below Sect. 4.6). We choose this peak as type locality. It consists in a regular and uniform alternation of centimetric to decimetric beds of white to light grey quartzites and darker calcareous sandstones, sometimes with thin layers of dark micaschists. At several places these quartzites have already drawn the attention of geologists who mapped them with a distinct signature (Burckhardt and Günthert 1957; Greco 1985; Huber 1981). A conspicuous level of quartzites has also been mentioned in the lower part of the Teggiolo calcschists father SW in Italy by Canepa (1993). This formation, more uniform than the Piano delle Creste sandstone, is easy to recognize and quite continuous, although its thickness varies considerably. It becomes thinner near Campo where it is only $10-20 \mathrm{~m}$ thick before it is cut at the 2,100 m elevation by the base of the wildflysch. It reappears in the Vanzèla cliffs $1 \mathrm{~km} \mathrm{~N}$ of Campo, forming the core of a large and complex isoclinal anticline (around 683.5/142.7; see below Sect. 4.6 and Fig. 10).

It is possible that the base of the Mèdola quartzite is unconformable. This would explain the thinning of the Pianasciom calcschist near Campo and its probable disappearance on the boundary crest. This point needs more 
detailed studies in the slopes above Campo and around the Kalberhorn.

\subsubsection{Age and stratigraphic interpretation of the calcschists of the third sedimentary cycle}

It would certainly be practical to lump these three formations together into a lithostratigraphic group that would correspond to the lower part of the Teggiolo calcschists. However, we think that before defining formally a type locality we need more detailed studies on their SW continuation in Italy (e.g. Canepa 1993). One would also wish to clear up the question of the possible existence of an unconformity at the base of the Mèdola quartzite. In the meantime we will continue to use the classical expression of Teggiolo calcschists in a somewhat loose way.

Our interpretation of the Antabia group involves a postJurassic age of the Teggiolo calcschists, in other words a Cretaceous to Tertiary age. The regional basal unconformity suggests an important stratigraphic gap. The Helvetic connection that proved to be a good guide for the two first sedimentary cycles now completely breaks. In the whole Helvetic s.l. domain no deposit of this age shows any similarity with the Teggiolo calcschists. The comparisons are now clearly on the side of the North-Penninic (or Valais sensu lato) domain.

The North-Penninic domain of the Alps is formed of several basins or sub-basins that had different histories during Triassic and Jurassic, but whose common point is their filling by thick detrital "flyschoid" sediments during Late Cretaceous and Tertiary. Many of these sediments are typical flysch sequences of turbiditic origin (Caron et al. 1989), e.g. the Niesen flysch or the Gurnigel and Schlieren flysches (that have a North-Penninic homeland according to a recent proposition of Trümpy 2006 that we accept willingly), while in other cases they can result from more complex deposition mechanisms combining gravity and bottom currents and can also incorporate detrital calcareous formations, e.g. in the Valais sensu stricto series of the Sion-Courmayeur-Tarentaise nappe (Trümpy 1954, 1955; Antoine 1971). The details of these flyschoid sequences vary considerably from one basin to the other but they all present a remarkable "family likeness", in sharp contrast with the sediments of same age in the Helvetic (adjacent to the NW) and Subbriançonnais (to the SE) domains. The well bedded and predominantly fine-grained, siliciclastic sediments that form the Teggiolo calcschists belong to this family.

The North-Penninic affinity of the Teggiolo calcschists is enhanced by the fact that everywhere in France, Italy and Western Switzerland where the North-Penninic flysches are not tectonically separated by a décollement from their earlier Mesozoic substratum, they overlie it with a pronounced angular unconformity underlined by a major stratigraphic gap. Typical examples are observed in the Niesen nappe, where the flysch discordantly overlies a substratum whose age varies from Triassic to Middle Jurassic (e.g. Badoux and Homewood 1978), or in the Tarentaise nappe where the Valais s.str. flyschoids are sharply unconformable on formations of Triassic and Jurassic age (e.g. Antoine 1971). These situations are very similar to the Teggiolo zone where the base of the calcschists can overlie the Jurassic to Early Cretaceous Antabia group, the Triassic dolomite or the Paleozoic Antigorio gneiss.

Everywhere where the North-Penninic flysches are well dated their base is latest Cretaceous (Maastrichtian) and their top Middle Eocene, e.g. in the Niesen flysch (Ackermann 1986) and the Gurnigel-Schlieren flysch (van Stuijvenberg 1979; Caron et al. 1989; top might even be Late Eocene, Ospina-Ostios et al. 2010). In Central Switzerland (Wägital and Iberg) the North-Penninic flysch deposits seem to start slightly earlier (Campanian) but still during the second half of Late Cretaceous (Winkler et al. 1985; Trümpy 2006). The Valais s.str. flyschoid series of the Sion-Courmayeur-Tarentaise nappe is commonly supposed to start during the Early Cretaceous but this stratigraphic hypothesis is probably wrong (Masson et al. 2008) and there is no evidence that its base is older than latest Cretaceous. Only in Eastern Switzerland (Graubünden) do North-Penninic flysches belong to continuous sequences of larger stratigraphic extent, but the truly flysch-like sediments, such as the Tomül flysch, are poorly dated and do not seem to start before a relatively advanced stage of Late Cretaceous (Steinmann 1994; Wyss and Isler 2007). In conclusion, by analogy with other North-Penninic series of the Western and Central Alps, we suggest a latest Cretaceous to Middle (Late?) Eocene age for the Teggiolo calcschists.

\subsection{Fourth sedimentary cycle: the Robiei wildflysch (Tertiary)}

\subsubsection{Introduction}

The upper part of the Teggiolo calcschists essentially consists in a uniform sequence of $\mathrm{mm}$ - to $\mathrm{cm}$-thick beds or streaks of various fine-grained detrital rocks, mainly calcareous and micaceous siltstones to sandstones, garnet micaschists and quartzitic sandstones. Although the bedding is usually well marked at a $\mathrm{cm}$ - to m-scale, on a larger distance it becomes irregular and discontinuous, contorted, or blurred, and from afar the general aspect is rather massive, contrasting with the conspicuous and regular layering of the Mèdola quartzite. Towards the top of the sequence the calcschists become more homogeneous and 
are often poorer in calcite and richer in garnet. However, the main characteristic of this formation is that it frequently contains blocks of exotic rocks of variable size. The whole complex of these blocks embedded in a more or less disordered flyschoid matrix presents all the characteristics of a wildflysch, analogous to typical wildflysches of central Switzerland (e.g. Trümpy 2006), the Prealps (e.g. Caron 1966; Weidmann et al. 1982; Kindler 1988) and the Valais s.str. domain of the French Alps (Masson et al. 2008). This thick and rather complex stratigraphic unit has been named the Robiei Formation by Masson (2002). According to the nature of the blocks, it is possible to distinguish three different associations that have specific vertical and lateral distributions.

\subsubsection{The Alpe Tamia-Campo wildfysch with blocks of marble}

This wildflysch forms the lower half of the Robièi formation in a zone that extends from Alpe Tamia (Italy, WSW of the P. Mèdola), through the steep southern and eastern slopes of the Basodino peak (Carreras and Jequier 2002), down to the surroundings of Campo. Most of the blocks are made of a white, pure calcitic marble, identical to the Sevinèra marble. More rarely they are yellowish or even brownish and made of more or less quartzic and micaceous limestone; in these cases the similarity is with the yellow member of the Sevinèra marble.

The first blocks are small and appear a few meters or decameters above the top of the Mèdola quartzite. Their size can be as small as a few $\mathrm{cm}$, like pebbles, but more frequently they are $\mathrm{dm}$ - to $\mathrm{m}$-wide and have a lenticular shape (Fig. 4). In its lower part the calcschist can also contain $\mathrm{cm}$-thick layers of yellow impure limestone that we interpret as calciturbidites. Higher up the blocks become

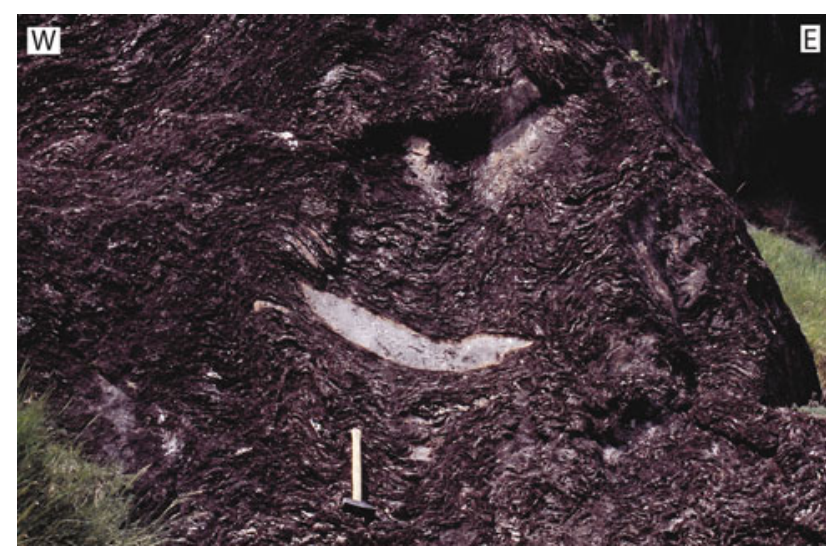

Fig. 4 Small blocks of marble at the base of the Alpe Tamia-Campo wildflysch (hammer for scale, ca. $45 \mathrm{~cm}$ ). Several marble pebbles dispersed in the calcschist matrix surround the main block. NW Campo (683.00/142.10)

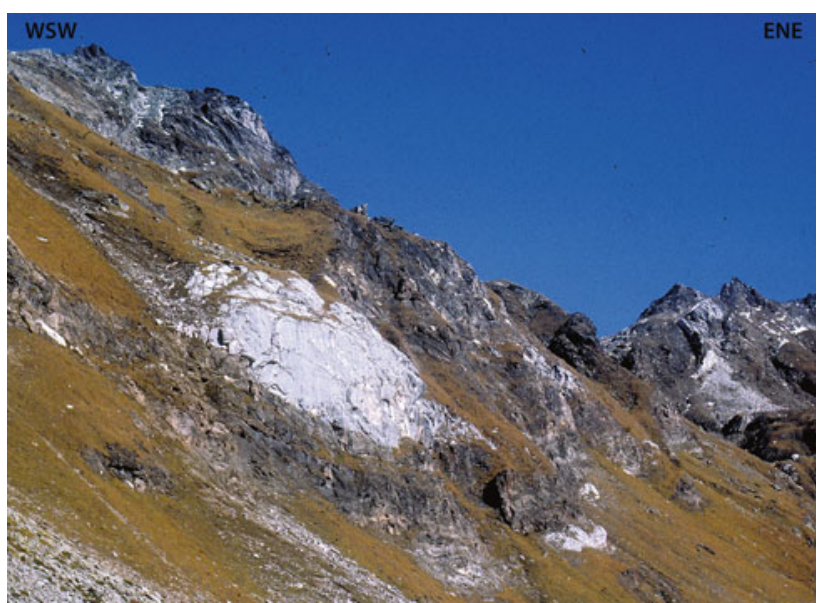

Fig. 5 Large block of marble in the Alpe Tamia-Campo wildflysch at Alpe Tamia. Smaller ones are also visible on the right. The crest is formed by the Lebendun gneiss thrusted over the Teggiolo zone. In the background: the Tamierpass

progressively larger (Fig. 5). They commonly reach a decametric length and detailed observation in good outcrops convincingly shows that they are completely surrounded by the calcschists in three dimensions. Finally they pass to very elongated slices of hectometric length with a thickness of several meters or decameters. Some of the largest ones, well visible in the high cliffs SE and E of the Basodino, have been mapped by Burckhardt and Günthert (1957).

The contact of this wildflysch upon the Mèdola quartzite is variable. At some places it looks sharp, at others transitional over a distance of several $\mathrm{m}$. Taking account of the fact that an unconformity might exist at the base of the Mèdola quartzite (see above), we have to allow for the possibility that this unconformity would mark the true base of the fourth sedimentary cycle and that the Mèdola quartzite would represent a first stage of normal, well stratified sedimentation in this cycle before the onset of the Alpe Tamia-Campo wildflysch. This question requires more detailed studies.

\subsubsection{The Tamier-Zött wildflysch with blocks of gneiss and lamprophyres}

This wildflysch forms the upper half of the Robièi formation in the sector from the Tamierpass (pt 2772 on the Swiss-Italian border; 679.100/139.220) to Robièi. In the Tamier area the first blocks of gneiss appear immediately above the wildflysch with blocks of marble (Carreras and Jequier 2002). Usually these two types of blocks are not mixed. This distinct distribution suggests two distinct events. The nature of the gneiss is variable, always different from the Antigorio as well as from the Lebendun gneiss. These gneisses can be either ortho or para, are often 
migmatitic and contain commonly a few small garnets. Sometimes they can also include thin brownish layers with a small amount of calcite. Bussien et al. (2011) provided zircon $\mathrm{U}-\mathrm{Pb}$ ages on an orthogneiss block from the Tamierpass $(285.9 \pm 7.2 \mathrm{Ma})$ and on a paragneiss block from Zött (from 2,400 to $483 \mathrm{Ma}$ ).

The size of the gneiss blocks progressively increases upwards in a way very similar to the marble blocks. At the base they are commonly dm- to m-large and the calcschist matrix can be locally enriched in coarse quartzic and feldspathic sand, tending to become arkosic, or in very small gneissic pebbles. At the top, in the cliffs below the Basodino peak, the blocks are really enormous and tightly packed in a rare micaschist matrix (Carreras and Jequier 2002). It is understandable that the accumulation of these huge blocks has been confused with the Lebendun gneiss that immediately overlies it and consequently was included into the Lebendun nappe on the sheet Basodino (Burckhardt and Günthert 1957). In the Basodino cliffs the Lebendun thrust is indeed situated 100-200 m higher than figured on this map. Gneiss blocks of all sizes are also numerous in the calcschists at Robièi (Fig. 6) and on the crest E of the Lago del Zött (1 km SW Robièi) (Della Torre 1995). However, here the Teggiolo zone is folded with the Lebendun nappe in a complex way and the geometric relations of the different wildflysch and gneiss types are more difficult to decipher.

A remarkable peculiarity of the gneiss blocks in the Tamier and Zött areas is that they frequently contain dykes of basic magmatic rocks (Carreras and Jequier 2002). These dykes are black or dark green, dm- to sometimes $\mathrm{m}$-thick, and frequently folded and boudinaged. Above the Tamierpass, where the accumulation of large blocks of migmatitic gneisses has been confused with the conglomeratic Lebendun gneiss, some of the boudinaged dykes have been noted on the Basodino map as pebbles of

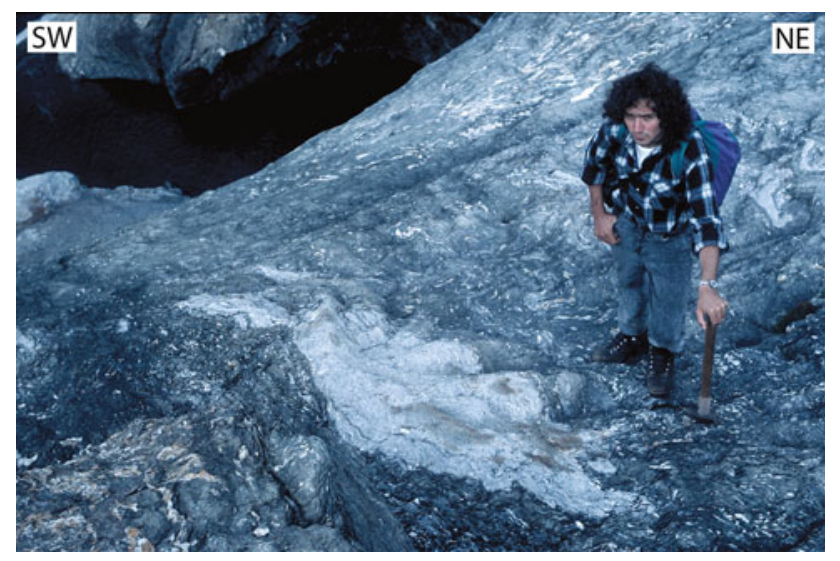

Fig. 6 Block of gneiss embedded in the calcschist matrix of the Tamier-Zött wildflysch. Smaller blocks are visible on the right. Bed of the Bavona river below the Cap. Basodino, Robièi (682.70/143.67) amphibolite in the conglomerate (Burckhardt and Günthert 1957). At Zött some m-large blocks in the calcschist are entirely made of the same basic rocks (Della Torre 1995). These rocks are anomalously rich in mafic minerals and are conveniently designed as lamprophyres. Their mineralogy and geochemistry has been investigated by Bussien et al. (2008). They mainly contain in various proportions biotite, hornblende, plagioclase, K-feldspar and epidote, sometimes accompanied by quartz or by large poekilitic crystals of clinopyroxene. Common accessories are apatite, titanite, chlorite, actinolite and rutile. Calcite is abundant at Zött: it is secondary but it is not clear if it results from exchange with post-magmatic fluids or with the calcschist matrix during Alpine metamorphism. At the Tamierpass these lamprophyres show an ultrapotassic trend (up to $6 \% \mathrm{~K}_{2} \mathrm{O}$ ). They can also be very basic $\left(\mathrm{SiO}_{2}\right.$ down to $\left.46 \%\right)$ and high in $\mathrm{Cr}$ and $\mathrm{Ni}$, which may result from local concentrations of amphibole and pyroxene in the center of the dykes. When these rocks were first mentioned by Masson (2002) the confusions between the different sorts of gneisses in the Basodino area (see above) were not yet cleared up and induced a suggestion that these dykes could be Mesozoic. Today it is obvious that this is not the case. Moreover, zircons from these lamprophyres have been dated by in situ methods (SHRIMP) and provided U-Pb ages of $284.8 \pm$ 1.7 Ma at the Tamierpass (Swiss side) and $290.0 \pm 1.3 \mathrm{Ma}$ at Zött (Bussien et al. 2008). Two additional lamprophyre samples from the Tamierpass (Italian side) have been recently dated by LA-ICP-MS at $286.5 \pm 5.3$ and $287.8 \pm$ 6.5 Ma (Bussien et al. 2011).

The gneiss blocks, so abundant from the Tamierpass to Robièi, suddenly disappear at this point. Only the blocks of marble continue to exist in the Robièi formation farther SE on the left bank of the Bavona down to the surroundings of Campo. The gneiss blocks also seem to disappear in Italy $1.5 \mathrm{~km} \mathrm{SW}$ of the Tamierpass. At Alpe Tamia the Lebendun thrust directly surmounts the wildflysch with blocks of marble.

\subsubsection{The Pizzo Castello wildflysch}

This complex forms spectacular outcrops in the cliffs of the Pizzo Castello (Fig. 7). It consists entirely in a thick accumulation of blocks of all sizes imbedded in the calcschists. The base of the pile lies directly on the Antabia group and its top is overlain by the Sambuco thrust.

Like in the other Robièi wildflysches the blocks show a conspicuous size gradient, but in this case it is stronger laterally than vertically. Coming from the $\mathrm{W}$, the blocks appear suddenly at Corte di Là (1 km W P. Castello) as elongated lenses of metric to decametric size (Fig. 8). However, very rapidly in the P. Castello they become gigantic and reach a hectometric or even kilometric length 


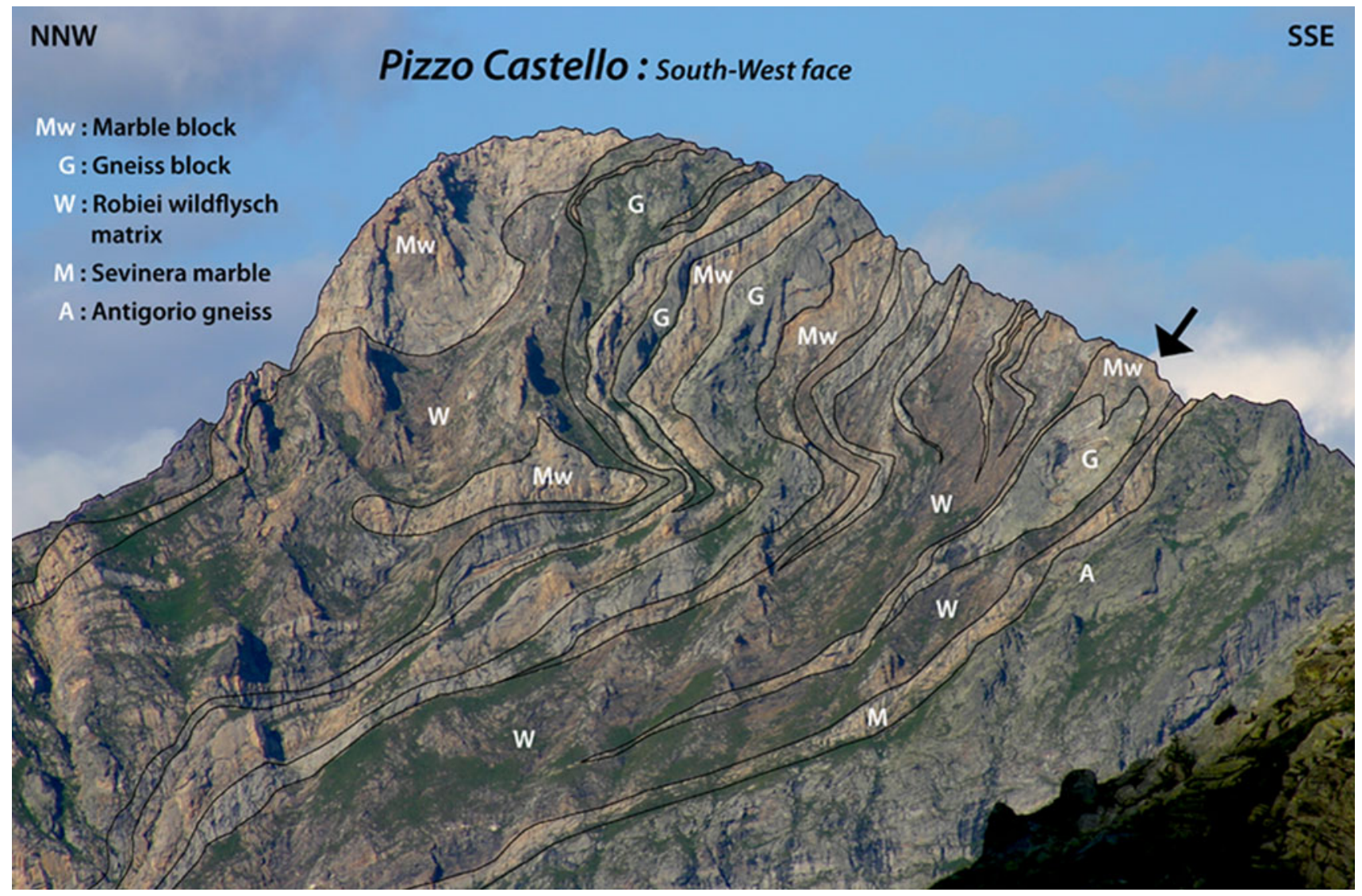

Fig. 7 Accumulation of very large blocks in the Pizzo Castello wildflysch. The arrow points to folds that existed before the formation of the blocks (height of cliff-face, ca. $300 \mathrm{~m}$ ). Photo D. Bussien

(Fig. 7). The marble quarry at Ghiéiba in Val Peccia is in such a giant block of marble. The excellent outcrops make it obvious that these blocks are not connected: one can observe at many places that they are separated one from the other and completely surrounded by the calcschist matrix. For the very large blocks whose size exceeds that of the outcrop this is more difficult to prove, but the gradual transition from the smaller to the larger ones looks convincing.

Three rock types can form these blocks: (1) A light grey, rather homogeneous gneiss, different from the Antigorio, the Lebendun, and the gneiss blocks of the Tamier-Zött wildflysch; (2) a coarse-grained calcareous sandstone, similar to the Sevinèra sandstone; (3) a white or yellowish to slightly brownish-reddish marble, similar to the Sevinèra marble. These three rock types are often associated in the same block. In this case the sandstone is always sandwiched between the gneiss and the marble (Fig. 9). Thus these composite blocks present an internal stratigraphic sequence identical to that of the Antigorio nappe itself below the wildflysch, but for the fact that the gneiss is different from the usual Antigorio gneiss. However, the thickness of the sandstone intermediate layer is variable: in some blocks it reaches several $\mathrm{m}$, in others it is much thinner and can even completely disappear (e.g. in the largest block of Fig. 7 where the contact marble/gneiss is repeated several times by folding). In this last case microscopic examination of thin sections through the contact reveals no hint of abnormal tectonization. This supports the interpretation of a stratigraphic contact: at these places the marble transgresses directly on the gneiss. The consequences of this fact will be developed farther (cf. Sect. 5.3).

In the classical literature (e.g. Günthert 1954, 1958; Burckhardt and Günthert 1957) the marble blocks are ascribed to the Triassic, the large blocks of the P. Castello being considered as tectonic slices ("Verschuppung") at the base of the Sambuco (formerly Maggia) nappe. However, a Triassic age is impossible for the same reasons as presented above (cf. Sect 3.3.6). The metasediments in the blocks are so similar to the Sevinèra marble and sandstone that their age must be the same. Moreover, there is no connection with the Sambuco nappe. More recently, Grujic and Mancktelow (1996) represented the structures of the P. Castello cliff as an example of superimposed folding. Folds of several generations are indeed numerous and spectacular 


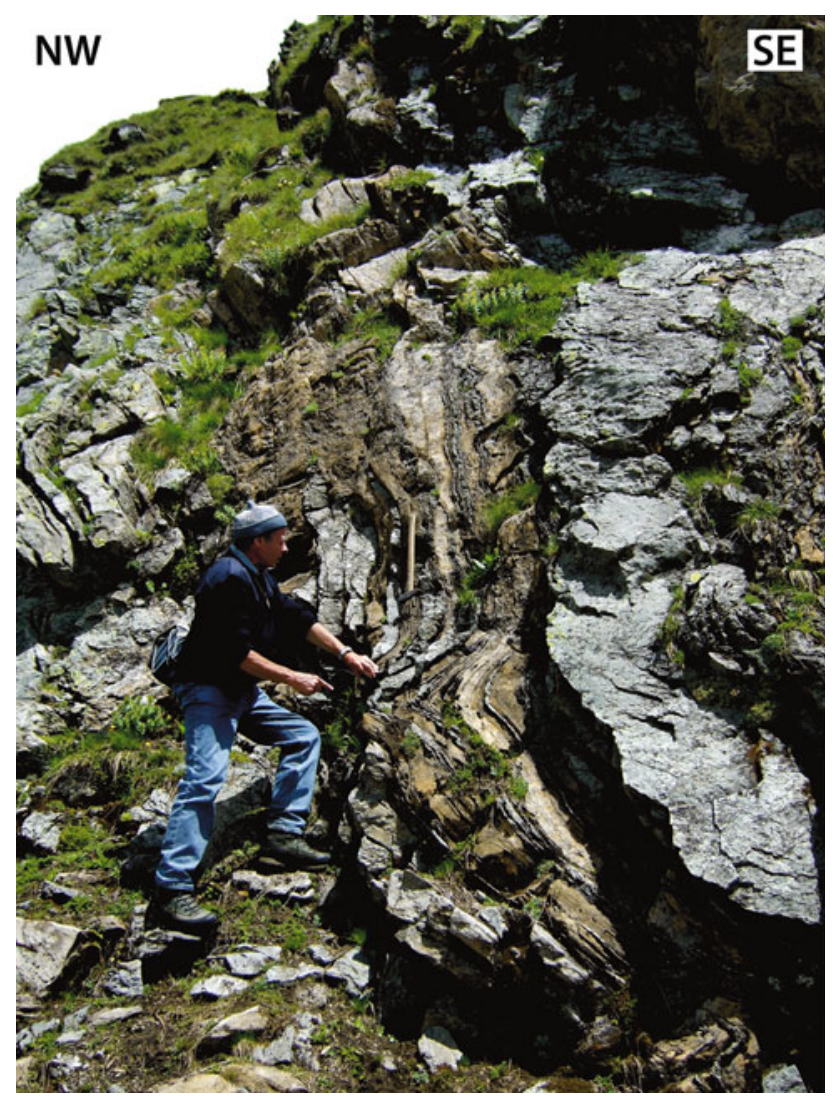

Fig. 8 Elongated blocks of gneiss (light grey) and marble (light yellowish) in the brown calcschist matrix of the Pizzo Castello wildflysch. Corte di Là, W foot of Pizzo Castello (685.82/141.39)

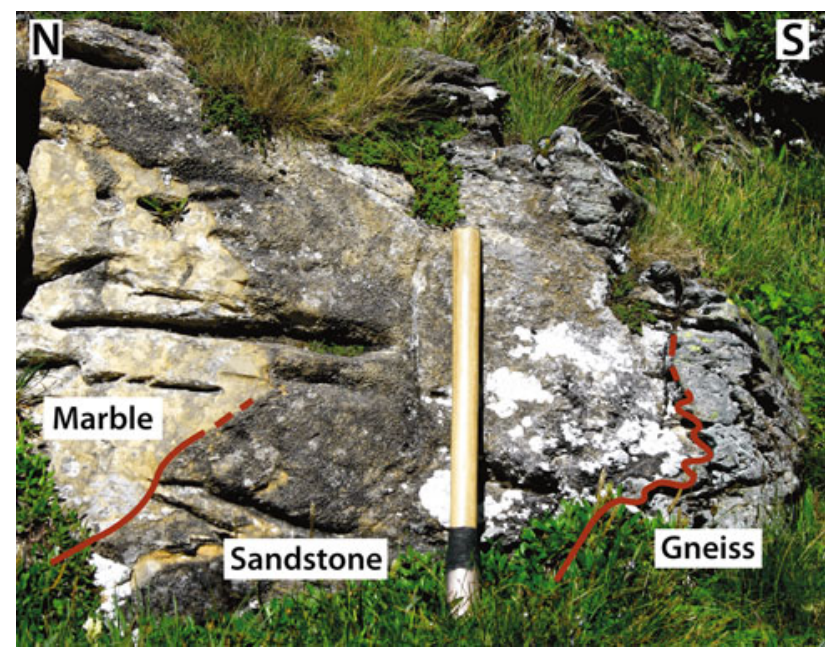

Fig. 9 Composite block of the Pizzo Castello wildflysch with the internal stratigraphic sequence marble/sandstone/gneiss (length of hammer shaft, ca. $60 \mathrm{~cm}$ ). Alpe Serodano, $1 \mathrm{~km}$ NE Pizzo Castello $(687.70 / 141.89)$

in this cliff. In some cases the blocks themselves are folded. In other cases the internal stratigraphy of a composite block is deformed by isoclinal folds that do not affect its border: just on the contrary the axial surfaces of these folds are cut by the limit of the block. In other words such folds precede the formation of the block. They might be the earliest Alpine folds presently known in the Lepontine Alps. One example in a large block is pointed on Fig. 7. This point will be developed below (cf. Sects. 4.4 and 5.6).

\subsubsection{Age of the wildflysch}

Even if our study reveals the existence of three different, well-characterized wildflysch units, it is practical to keep the name of Robièi Formation for grouping them altogether. Their origin will be discussed farther (cf. Sect. 5.2). The dating of the Robièi wildflysch can only be indirect and results from the stratigraphic considerations presented above (cf. Sect. 3.4.5). The end of flysch sedimentation in the North-Penninic basins, e.g. in the Niesen or the Gurnigel nappes, takes place near the turn of Middle to Late Eocene. Consequently a latest Middle Eocene or early Late Eocene age of the Robièi wildflysch is probable.

\section{Tectonics}

\subsection{Introduction}

The structure of the Antigorio nappe in the Val Bavona results from at least four phases of deformation (D1-D4) whose succession is revealed by the superimposition of the corresponding schistosities (S1-S4) and by the interference patterns of the corresponding folds (F1-F4). However these structures are not distributed uniformly in the different parts of the nappe, even in this relatively small area. All four phases together are observed at their best in the Teggiolo metasediments at the front of the nappe above Campo.

\subsection{The Antigorio frontal fold F3 and the Castello folds}

The large-scale curvature of the Antigorio gneiss above Campo (Fig. 10) is commonly ascribed to the frontal hinge of the Antigorio fold-nappe, i.e. the equivalent of the large isoclinal recumbent fold drawn by Gerlach (1869) in his historical cross-section of the Lepontine Alps. Although alternative correlations have also been proposed (Huber 1981; Steck et al. 2001), we subscribe willingly to this tectonic reconstruction that we consider as the most probable solution.

The corresponding small folds are recognized from their moderately plunging ENE axes $\left(0-35^{\circ}\right.$ towards $\left.50-65^{\circ}\right)$, their moderately dipping axial planes and their "S" (NWvergent) asymmetry (with local exceptions in the inverse limbs of second order folds, see below). Their shape is 


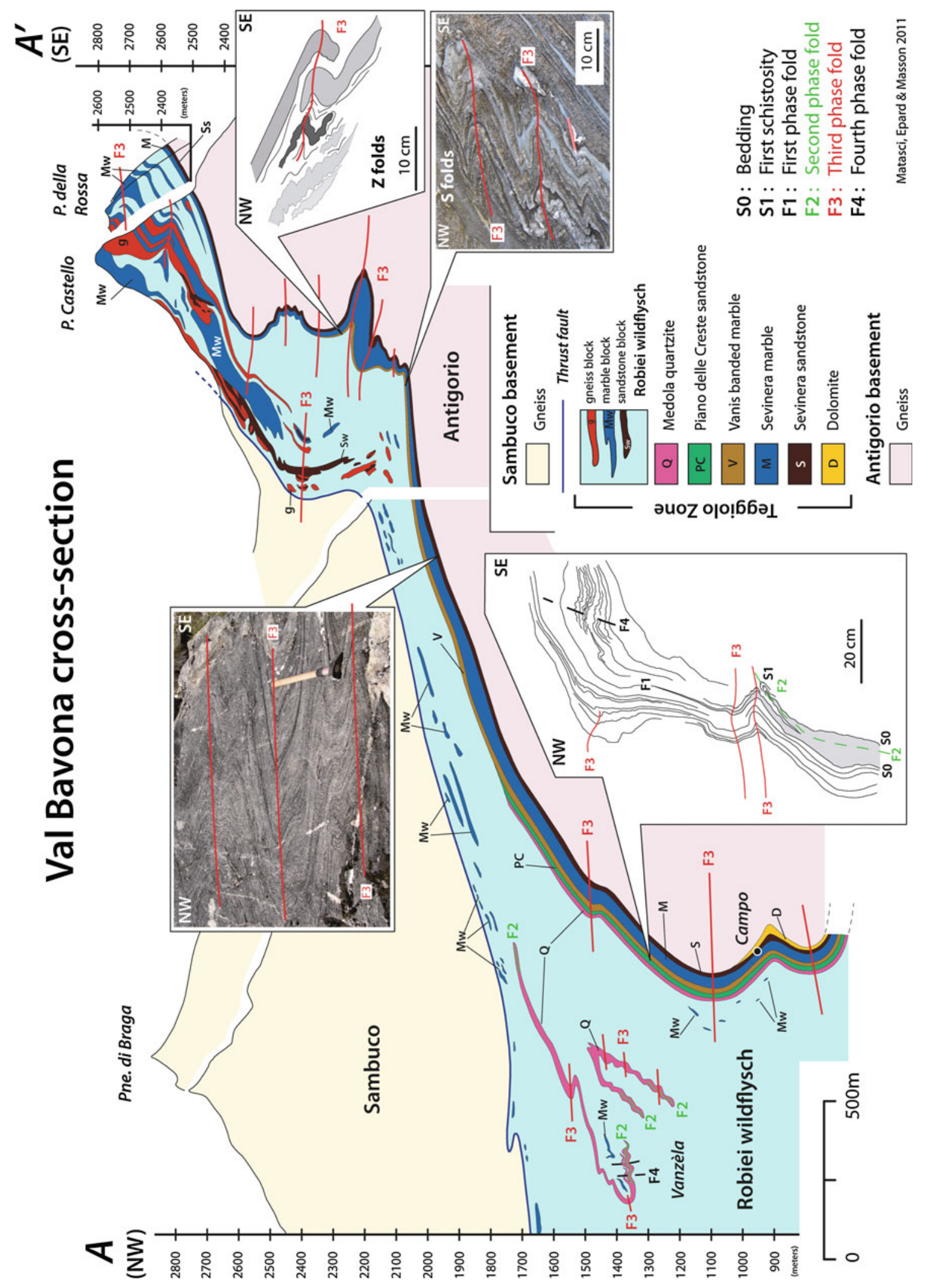

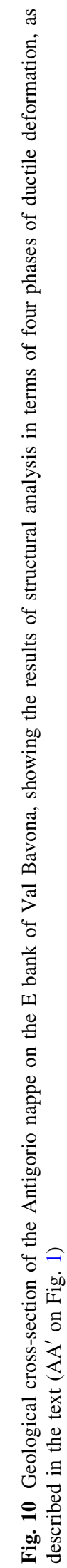


Fig. 11 Small-scale example of the superimposition of four phases of deformation in the Vanis formation NE of Campo (683.63/142.07)

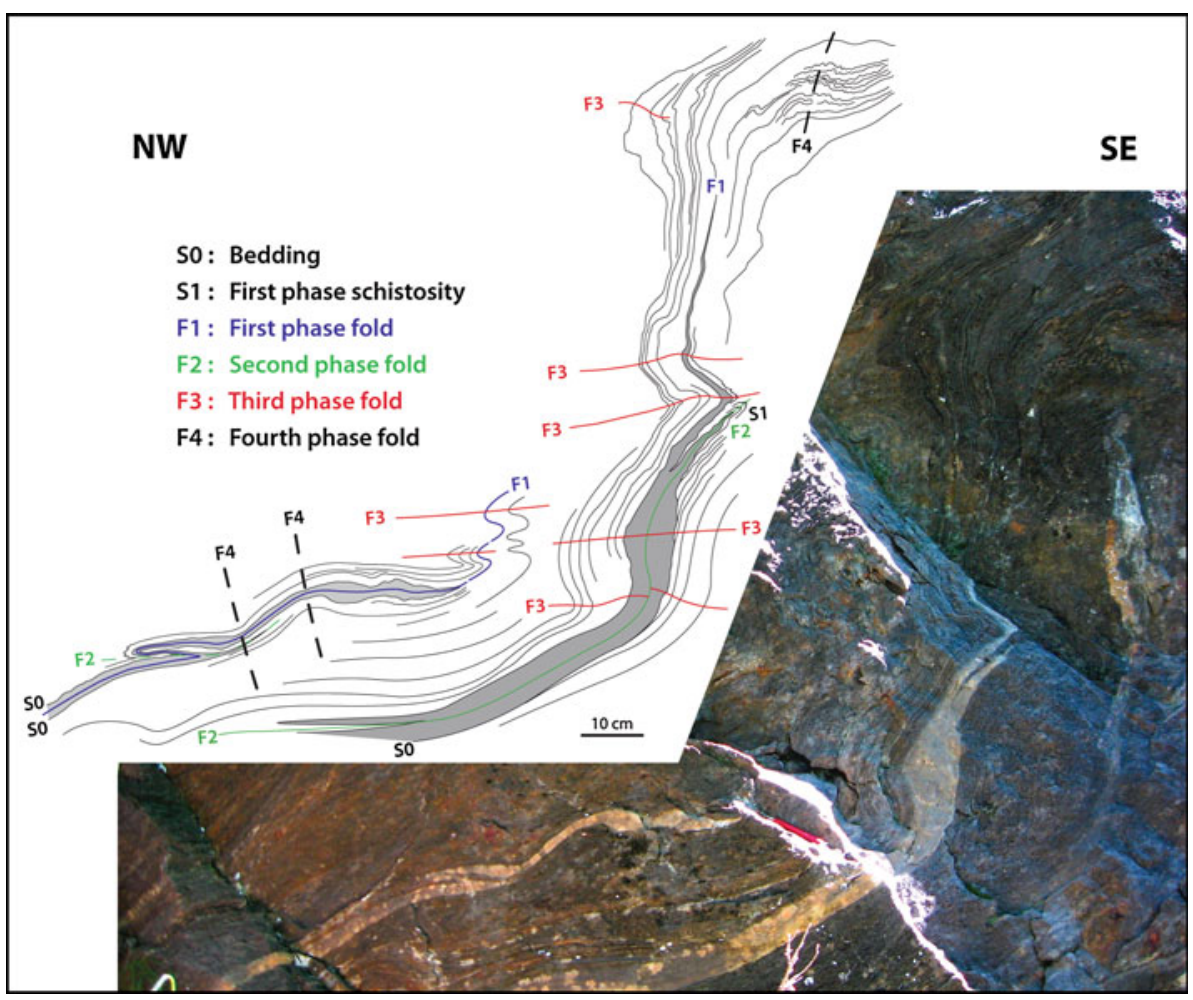

variable, from open to isoclinal, but often tight or close, with rounded hinge zones. In the Teggiolo metasediments they clearly refold two generations of older folds (Figs. 10, 11) and therefore are numbered F3. They commonly crenulate older schistosities $\mathrm{S} 1$ and $\mathrm{S} 2$, but can also develop a new axial plane schistosity S3. Consequently the frontal hinge of the Antigorio nappe is a third phase fold.

At the SW foot of Pizzo Castello, between Castello di Sotto and Castello di Sopra (around 685.8/140.7), a pair of complementary recumbent folds of hectometric amplitude, a syncline and an anticline, spectacularly affect the cover/ basement contact and the whole Teggiolo zone (Burckhardt and Günthert 1957; Huber 1981; Grujic and Mancktelow 1996 Fig. 8b). Although the syncline is not quite as tight as it apparently looks on the map, because of a subparallel intersection with topography, the sediments are pinched into the basement in a way that contrasts with the much more rounded hinge of the anticline, a geometry that typically illustrates the effect of the difference of ductility between basement and cover (Ramsay 1967). This pair is moreover decorated by numerous smaller folds whose orientation, style, and relations with the schistosities are identical to those of the small F3 mentioned above. The asymmetry of these smaller folds is of " $\mathrm{S}$ " type in the lower, normal limb of the syncline, and of " $Z$ " type in its upper, inverse limb (Fig. 10). This demonstrates their synchronism. Thus, the Castello folds are also F3. They are second order folds on the normal limb of the Antigorio nappe.
These two folds obviously correspond to a similar pair of folds in the Val Antabia, $5 \mathrm{~km}$ to the SW on the opposite side of the Val Bavona (also mapped by Burckhardt and Günthert 1957; Huber 1981). The analysis of the associated small structures at Antabia ("S" and "Z" F3) confirms this correspondence, which indicates a mean axial plunge of $3^{\circ}$ towards $245^{\circ}$ through the Val Bavona. These values are in agreement with the subhorizontal or even weakly WSW plunging axes of the folds in the Val Antabia, while they start plunging towards ENE (i.e. towards the Maggia crosssynform, Steck 1998) on the left bank of the Bavona.

The Castello folds affect the thrust surface of the Sambuco nappe (Fig. 10). It is not known if this thrust is also deformed by the frontal hinge of the Antigorio nappe but, as this hinge is also a F3, it might be expected that this should be the case.

\subsection{The older deformations D1 and D2}

At the scale of the outcrop, F3 folds frequently refold older structures. These are very tight to isoclinal, with angular, tapered hinges, and they usually approximate the similar class of folds. Their strong axial plane schistosity is commonly the dominant planar structure of the rock.

These folds are visible at their best where the rocks show good lithostratigraphic contrasts, such as the alternating marble and calcschist beds of the Vanis Formation and the quartzite beds of the Mèdola Formation. 
Examination of good outcrops in these rocks reveals at least two superimposed systems of folds (F1 and F2) and related schistosities ( $\mathrm{S} 1$ and $\mathrm{S} 2$ ) in these early structures (Fig. 11). The oldest ones (F1) are only recognizable with certainty when they are refolded by a F2. They have perfectly parallel limbs and extremely elongated and tapered hinge zones. Their vergence and axial direction are usually impossible to determine. Their schistosity S1 is rarely preserved, but it occasionally happens that remnants of $\mathrm{S} 1$ are observable, turning around the hinge of a F2.

The F2 folds have the same general style although they are often not quite so elongated and their interlimb angle can reach $10-20^{\circ}$. Because of variable axial directions their interference patterns with the other generations of folds can be of type 3 or 2 (classification of Ramsay 1967). Their axial plane schistosity $\mathrm{S} 2$ is dominant and may show a slight but distinct obliquity to the bedding and to the F1 axial surfaces. They generally have an "S" (N- to NWvergent) asymmetry (looking $\mathrm{NE}$; local exceptions see below). The obliquity of S2 to the bedding confirms the vergence towards NW. The geometry of all these early folds suggests the superimposition of a strong component of homogenous strain on the original folds. F2 folds of hectometric size deform the thrust surface of the Sambuco nappe above Vanzèla and at Robièi.

\subsection{The pre-wildflysch folds $\mathrm{F}(-1)$}

Blocks and lenses of the Robièi wildflysch sometimes show isoclinal folds that are truncated by the limit of the block. Good examples can be observed in the Pizzo Castello cliff in composite blocks that are made of two or several layers with a good lithological contrast, such as the stratigraphic succession marble/sandstone/gneiss (cf. Sect. 3.5.4 and Fig. 7). These folds obviously precede the formation of the blocks and are thus older than the wildflysch. Consequently the source of the blocks is in an area that was already affected by Alpine folding when the Robièi wildflysch was formed.

As these folds are older than the most recent sediments of the Teggiolo domain, and as sedimentation determines the bedding that is the zero reference (SO) for numbering the phases of deformation, these folds should be numbered, strictly speaking, $\mathrm{F}(-1)$ with respect to the structural chronology established in this part of the Antigorio nappe. However, it is clear that in the local chronology of their source area, that we think to be a more internal part of the Antigorio nappe (see below Sect. 5.2), they occupy a D1 (or more) position. This highlights the difficulties of correlating old phases of deformation between different sectors, even within the same tectonic unit.
4.5 The younger F4 folds

In the gorge of the Bavona river $\mathrm{N}$ of Campo, the structures of the Teggiolo calcschists, including those of the D3 phase, are overprinted by folds of decimetric to decametric size with a NE trending, vertical axial plane and weakly plunging $\mathrm{NE}$ axes (about $10^{\circ}$ towards $40-50^{\circ}$ ). They are often straight-limbed, with angular or rounded hinges and interlimb angles generally comprised between 10 and $70^{\circ}$, sometimes down to $0^{\circ}$. They can be symmetric ("M") or asymmetric, in this case with dominance of the " $Z$ " asymmetry (looking NE). As they are younger than all the other ductile structures we number them F4. They are sometimes associated with a weak crenulation cleavage S4.

The strongest development of these folds is limited to $\mathrm{a} \leq 1 \mathrm{~km}$ wide couloir that seems to run above and immediately ahead of the probable position of the frontal hinge of the Antigorio gneiss. Out of this zone the D4 deformation quickly weakens and the F4 folds become more rare and gentle (Fig. 11).

\subsection{The Vanzèla fold}

The steep slope of the Val Bavona about $1 \mathrm{~km} \mathrm{~N}$ to NE of Campo, between Vanzèla and Zota (around 683.5/142.7), shows a $900 \mathrm{~m}$ long and several meters to decameters thick band of Mèdola quartzite completely surrounded by the Robièi wildflysch (Fig. 10). It is a tectonic repetition of the Mèdola into the Robièi Formation, with observable hinges, in other words it is an isoclinal anticline. We call it the Vanzèla fold. Although detailed control is difficult because of hard access, this band does not seem to connect on the map with the Mèdola quartzite in its normal position below the Robièi formation. It must be a sheath fold with a curved hinge line that goes "into the air" at both extremities, with a local mean axial plunge towards $285^{\circ}$. Shorter, similar bands below the main one represent second order folds.

The lower extremity shows interesting complications in the cliff E of the Campo-Robièi pathway. It is deformed in a complex way that illustrates the superimposition of the successive phases of folding. The isoclinal anticline is folded by a tight recumbent F3 of decametric size that is itself strongly affected by a multitude of upright F4 of metric amplitude. Although detailed examination of the isoclinal hinges in the cliff is difficult, it seems that they refold older tectonic veins. For this reason we ascribe the Vanzèla fold to D2. Well visible third-order F2 folds of metric size have a " $\mathrm{Z}$ " asymmetry (looking NE), thus suggesting at first sight a SE vergence, but they are on a former inverse F2 limb that is placed again in a normal stratigraphic position on the lower limb of the recumbent F3. The true overall vergence is indeed towards $\mathrm{N}$ or NW. 
Possible correlations with other large folds of the Antigorio nappe offer interesting perspectives. Detailed mapping of the Val Antabia by Carreras and Jequier (2002) has in a similar way revealed a large isoclinal anticline of Mèdola quartzite forming a $200 \mathrm{~m}$ thick intercalation in the Robièi wildflysch, $1.5 \mathrm{~km} \mathrm{SE}$ of the Basodino peak. Towards the NE, this band of quartzite disappears in the inaccessible cliffs $\mathrm{S}$ of the Pizzo Pecora, but a connection with the Vanzèla fold above the Bavona river is a very serious possibility. The general NE trend of this connection would not contradict the local WNW axial direction observed at Vanzèla, as this fold typically has a sheath geometry. The quartzite anticline of the Val Antabia presents all the characteristics of a F2 fold. Towards SW this anticline merges with the normal Mèdola quartzite at the Pizzo Mèdola, which explains the great thickness of the quartzite in this mountain. However, this is not all: $1 \mathrm{~km}$ SW of the Pizzo Mèdola, the Kalberhorn peak, on the ItaloSwiss border crest (Fig. 1), presents a surprising complication (Schmidt and Preiswerk 1908a, b; Greco 1985; Carreras and Jequier 2002) that could well be explained by a large F2 anticline of Antigorio gneiss, enveloped by the Teggiolo metasediments and deformed by superimposed F3 and F4 folds. This proposition needs to be submitted to a detailed structural analysis of the Kalberhorn area. If it is confirmed, the Kalberhorn would appear as the "crystalline" core of the Mèdola-Vanzèla anticline.

Still farther SW, on the western side of the Toce above Valdo, the Antigorio nappe is complicated by a tight recumbent gneiss anticline (Joos 1969; Favey 1999; Steck et al. 1999). A structural analysis remains to be done, but the style of this fold, characterized by a thin, angular hinge, suggests a F2 structure. If we project the Kalberhorn fold with a reasonable mean axial plunge of $15^{\circ}$ towards WSW, it falls exactly on the Valdo anticline. These geometrical relations support the hypothesis of a Valdo-KalberhornMèdola-Vanzèla F2 anticline of $\mathrm{km}$ size, in which the Valdo and Kalberhorn areas would represent the gneissic core and the Vanzèla area the "nose" at the level of the Robièi/Mèdola interface.

\section{Discussion}

5.1 The Teggiolo zone: the missing link between Helvetic and Penninic

Our stratigraphic reconstruction reveals the critical role of the Teggiolo zone in the Helvetic-Penninic connection:

1. During the Triassic, Jurassic and Early Cretaceous, the affinity of the Teggiolo sedimentary sequence is clearly with the Helvetic s.l. realm, and at Mid-Jurassic times more especially with the paleogeographic highs or thresholds separating its different basins (cf. Sect. 3.3.6). The Antigorio-Teggiolo sector appears to represent the southern limiting rise of the main Helvetic Jurassic basin.

2. At the end of Cretaceous, the sedimentary record dramatically changes: the well-bedded, essentially finegrained siliciclastic Teggiolo calcschists present striking analogies with the deep-water flyschoid deposits that characterize the North-Penninic (or Valais s.l.) basins, in total contrast with the neighboring Helvetic and Subbriançonnais-Briançonnais domains (cf. Sect. 3.4.5). One could say that the Teggiolo switches from the Helvetic to the North-Penninic, or that the Valais s.l. sediments spread over the southernmost territories of the Helvetic realm.

This conclusion is not entirely new: several authors have already suggested a paleo-position of the Antigorio nappe on a paleogeographic threshold limiting the Helvetic domain to the south and separating it from the North-Penninic (e.g. Masson et al. 1980 Fig. 5; Leu 1986; Spring et al. 1992 Fig. 5). However at that time any attempt of a more elaborate paleogeographic interpretation was dampened by extreme uncertainties on the age of the sediments and on the homeland of the different tectonic units. Our stratigraphic reconstitution of the Teggiolo zone opens the door to a much more precise reconstruction in space and time.

As in other North-Penninic series, the Triassic to Early Cretaceous and the Late Cretaceous to Eocene sections of the Teggiolo sequence are separated by a marked unconformity and a large stratigraphic gap that correspond to a turning point in the sedimentary history of this part of the Alps. The origin of this unconformity remains one of the great problems of Alpine geology. A more detailed discussion would be out of the scope of this paper, but we suggest that it results from a rather sudden tectonic event of regional importance, maybe the beginning of subduction in the North-Penninic domain.

In any case, one point seems to emerge: the Late Cretaceous-Tertiary Valais s.l. flyschoid sedimentation unifies basins that had very different previous histories. For instance the Valais s.str. flyschoid series of the SionCourmayeur-Tarentaise nappe overlies Jurassic limestones of Subbriançonnais type and Triassic formations that display characteristic features of the Briançonnais Triassic (Elter and Elter 1965; Antoine 1971). Work in progress by one of us (H.M.) shows that the Niesen flysch also lies on a substratum whose Triassic layers typically belong to the Briançonnais Triassic platform. On the contrary, the NorthPenninic Teggiolo calcschists are superimposed on a Triassic-Jurassic substratum of Helvetic affinity. These features reveal a drastic paleogeographic and geodynamical 
reorganization of the European margin of the Alpine Tethys at the end of Cretaceous.

\subsection{Origin of the Robièi wildflysch}

The internal constitution of the Robièi Formation corresponds in every respect to the definition of a wildflysch, the only difference from a classical wildflysch of the Central Swiss klippes or the Prealps (e.g. Caron 1966; Weidmann et al. 1982; Kindler 1988; Trümpy 2006) being its high metamorphic grade. The genesis of a wildflysch, after more than one century of research and passionate discussions, is still controversial. A complete review is outside the scope of this paper. If we try to summarize, it seems today that many geologists are ready to agree that a wildflysch can result from a combination of sedimentary (s.l.) and tectonic processes in an early orogenic context: (1) At the start, gravity-driven down-slope mechanisms such as submarine landslides (olistostromes) and megaturbidites play a major role; at this stage the blocks are often supposed to be provided by the front of an advancing nappe of more internal origin, before its arrival closes the basin, putting an end to its sedimentary history. (2) Once the basin is closed it may happen (or not) that tectonic mechanisms take over during subduction and thrusting and superimpose a strong penetrative shearing that will increase the degree of complexity; at this stage the wildflysch can incorporate blocks from a much wider range of sources, including sources that are stratigraphically or structurally lower. The Prealps show examples of all the transitions from relatively simple wildflysches of submarine origin, whose blocks have a monogenic source, such as the Ultrahelvetic (s.str.) wildflysches of the Internal Prealps (Lempicka-Münch 1996), to totally chaotic complexes such as the Zone Submédiane (Weidmann et al. 1976) that seemingly can only result from a succession of sedimentary and tectonic events.

In the case of the Robièi wildflysch, a sedimentary s.l. interpretation (olistostromes, etc.) seems hard to avoid. The relatively good preservation of the original bedding at small scale in the calcschist matrix, and the very gradual vertical transition from fine-grained calcitic detritus to the largest marble blocks and slices, are conclusive evidence of the sedimentary origin of the Alpe Tamia-Campo wildflysch. Similar observations can be made on the gneissic component of the Tamier-Zött wildflysch. Also in the P. Castello wildflysch, the continuous transition from small blocks embedded in a sedimentary matrix to the largest slices is striking.

A tectonic contribution to the genesis of the Robièi wildflysch is much less evident. It is possible (but hard to prove) that some marble or gneiss lenses have been boudinaged during tectonic deformation, adding a minor tectonic contribution to the formation of the blocks. An interesting case is provided by the Mèdola quartzite in the Vanzèla complex fold (cf. Sect. 4.6). These quartzite bands, isoclinally folded in the calcschists, might look at first sight like slices "floating" in the wildflysch matrix, all the more since they are not connected on the map with their root and the curved hinge lines cut the $2 \mathrm{D}$-cross section (Fig. 10) twice, at each extremity of the bands. Only detailed mapping of the steep slopes around Vanzèla suggests that they originally were connected in 3D. Starting from this situation, it is easy to imagine that with increasing strain these bands could become boudinaged and fragmented into truly independent slices that would add a component of tectonic origin to the wildflysch. This just did not happen, but it would plausibly have been the next stage in the development of increasing complexity. This provides a model of how various elements can be tectonically incorporated from a lower source into a wildflysch of primarily sedimentary origin, transforming it into a more chaotic, polygenic mélange.

The main problem of the Robièi wildflysch is now the origin of the blocks: where is (are) the source territory(ies) that provided them? Absence can be as significant as the presence of a particular rock type for discussing this question:

1. The marble blocks are poor indicators. During Late Jurassic, pure calcareous (hemi)pelagic muds, able to be transformed by metamorphism into a marble of Sevinèra type, were the dominant sediment over wide areas, including most of the Helvetic realm and several Penninic basins. They are all potential sources of marble blocks.

2. The gneiss blocks with lamprophyres of the TamierZött wildflysch give better clues. Late-Variscan lamprophyres exist in several basement units of the Central Alps (Oberhänsli 1986), but we observe a striking similarity of the Tamier lamprophyres with the lamprophyric dykes of the nearby Sambuco nappe (for field descriptions, mineralogy, geochemistry and ages of these dykes see Ramsay and Allison 1979; Steiner 1984; Günthert et al. 1996; Galli et al. 2007; Bussien et al. 2008, 2011). They have similar geochemical characteristics (notably the same ultrapotassic trend) and the same age range around $290 \mathrm{Ma}$. As for the gneisses, the lack of a modern inventory of the numerous types of gneisses existing in the Sambuco nappe prevents any detailed comparison. We can only say that, at the present state of knowledge, we are aware of no incompatibility between the blocks in the wildflysch and the gneisses of the Sambuco basement. In conclusion, the Sambuco nappe, or an unknown territory originally adjacent to it and with a similar 
Paleozoic basement, appears to be a serious candidate for the source of the blocks of the Tamier-Zött wildflysch (Bussien et al. 2008, 2011).

3. The solution involving an adjacent territory is to be preferred, because the Sambuco nappe has a specific sedimentary cover (Délèze 1999; Lodetti 2001; work in progress) which should be represented among the blocks if this nappe was their source. However, rocks typical of the Sambuco cover are completely absent from the Robièi wildflysch. A reasonable hypothesis is that the Mesozoic cover of this unknown territory was essentially made of marbles of Sevinèra type: a first event of erosion and massive sliding would have destroyed it, providing the blocks of the lower (Alpe Tamia-Campo) wildflysch and denuding the basement. Then a second event would have eroded this exposed basement, generating the upper (Tamier-Zött) wildflysch. We call this hypothetical territory Tamia: it would combine a Paleozoic basement of Sambuco type (i.e. the source of the gneissic-lamprophyric blocks of the Tamierpass) and a Mesozoic cover of Sevinèra type (i.e. the source of the marble blocks of Alpe Tamia). Its original position should be between the homelands of the Antigorio and Sambuco nappes. We will see below (cf. Sect. 5.4) that this proposition is also supported by paleogeographic considerations.
4. The composite blocks of the Pizzo Castello are particularly interesting. Their internal stratigraphic sequence marble/sandstone/gneiss is identical to that of the Antigorio nappe itself, except for the gneiss which is different. These blocks could come from a more internal part of this nappe where the usual Antigorio gneiss would be absent. The strong lateral size gradient of the P. Castello blocks (cf. Sect. 3.5.4) suggests a proximal source at the rear of the Antigorio nappe. In this context it is important to note that the Teggiolo zone disappears $5 \mathrm{~km}$ ENE of the P. Castello at the foot of the P. Mascarpino (Preiswerk 1912; Günthert 1954; Keller et al. 1980; Berger and Mercolli 2006). Classically this disappearance is considered as a case of extreme thinning by shearing during nappe movement. We suggest here an alternative possibility: that in the rear of the Antigorio nappe the basement was denuded by a massive erosion of its sedimentary cover, due to gravity-driven sliding at an embryonic stage of nappe tectonics, before it was re-covered by the Sambuco nappe (Fig. 12). The products of this erosion would form the P. Castello wildflysch.

5. Finally it is important to underline the absence from the Robièi wildflysch of any block akin to the Lebendun nappe, which directly overlies the Antigorio nappe along most of its length. This shows that this
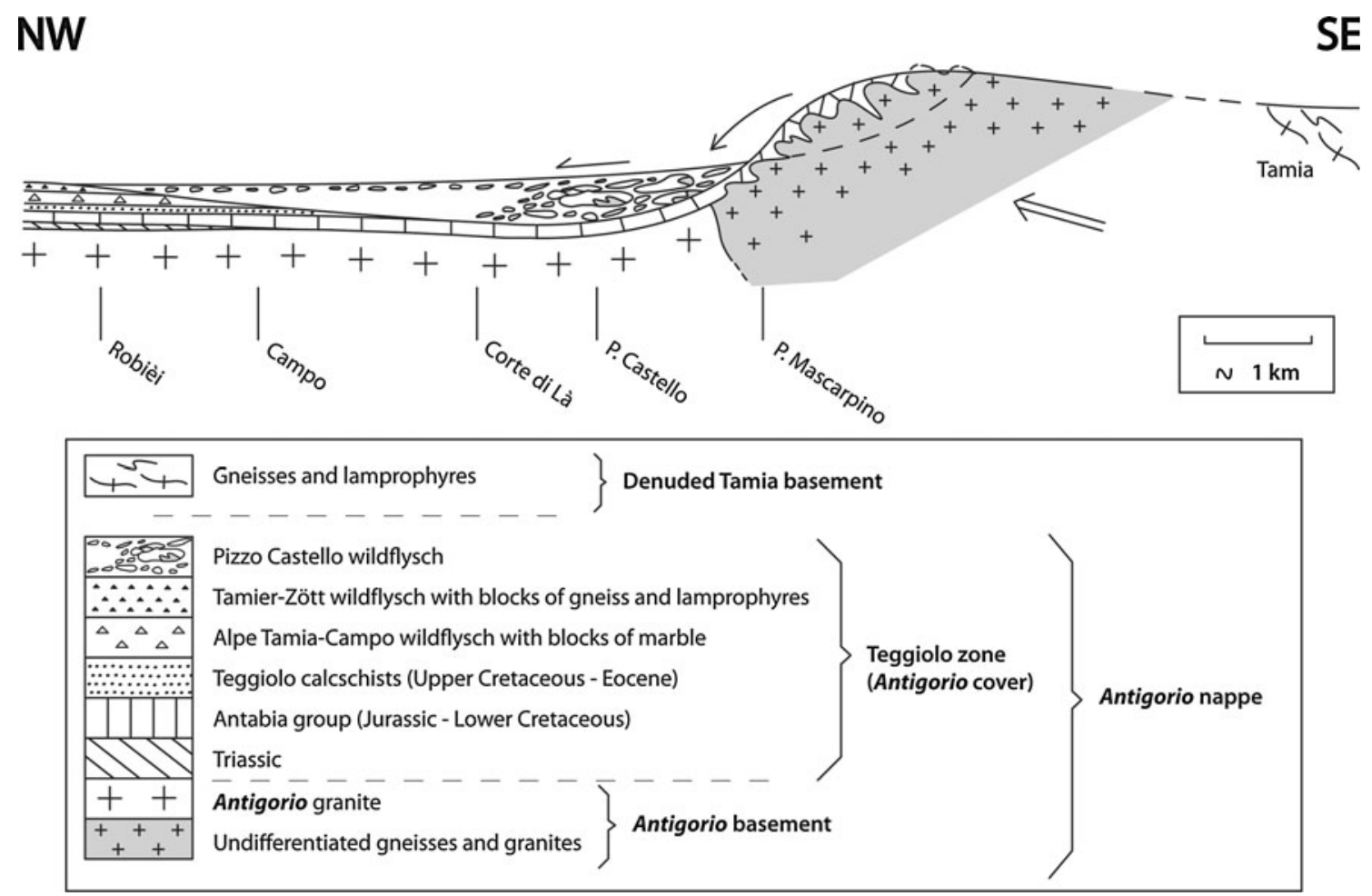

Fig. 12 Conceptual model of the Pizzo Castello wildflysch trough. The hypothetical Tamia land is inferred from the composition of the blocks of the Tamier-Zött and Alpe Tamia-Campo wildflyschs (see text). The arrows represent, from right to left, the "orogenic push", the collapse of the folded Pizzo Castello blocks, and their sliding on the bottom of the sea 
nappe did not cover the source territories of the blocks before the end of the wildflysch formation.

Preliminary reconnaissance work points to the continuation of the Robièi wildflysch in the upper part of the Teggiolo calcschists in Italy. At several places, the blocks are rarer but they are never completely absent over long distances. For instance, above Goglio (Val Dèvero, $20 \mathrm{~km} \mathrm{~N}$ Domodossola) a $200 \mathrm{~m}$ thick calcschist formation lying between a probable equivalent of the Mèdola quartzite and the Lebendun thrust is devoid of blocks. But only $1 \mathrm{~km} \mathrm{~N}$ of Goglio, along the road and on the old path to Alpe Dèvero, the top of the same calcschist (repeated by an isoclinal fold of the Lebendun/Teggiolo thrust) is locally rich in small blocks of marble and gneiss. Father SW above Ciamporino (17 km NNW Domodossola), the Teggiolo calcschist looks similar to the Robièi wildflysch and contains white marble blocks of decametric size. The Ciamporino quarry (Cava di Calcare) is probably dug into a giant block of marble. On the neighboring Monte Cistella, Milnes (1964, 1965) mapped marble lenses (called "stink-marble") in the calcschists, up to $5 \mathrm{~m}$ thick and $150 \mathrm{~m}$ long. Still father $\mathrm{SW}$, in the bottom of Val Cairasca $(3 \mathrm{~km} \mathrm{~W}$ San Domenico), several hectometric-long and decametricthick lenses of garnet gneiss seem to be completely surrounded by the Teggiolo calcschist and are surmounted by a long marble slice, immediately below the Lebendun thrust. Spring et al. (1992) already suggested that these gneiss lenses (their G1 gneiss) could be blocks embedded in the calcschist. One $\mathrm{km}$ to the $\mathrm{S}$, these authors also found a unique, $150 \mathrm{~m}$ long and $5 \mathrm{~m}$ thick slice of tremolite-rock incorporated into the Teggiolo calcschist, unfortunately in poor outcrop conditions. Last but not least, on the mountain crest $\mathrm{E}$ of Val Antigorio (P. Bronzo, pt. 2502, $16 \mathrm{~km}$ NNE Domodossola), reconnaissance work by Maggini (1999) and one of us (H.M.) revealed the presence in the Teggiolo zone (between the Triassic cover of the Antigorio gneiss and the thrust of typical Lebendun gneiss) of a calcschist rich in meter- to decameter-large blocks of gneiss, marble and various metabasites. It must represent a lateral variation of the Robièi wildflysch. The age and origin of these metabasites, among which we note conspicuous blocks of garnet amphibolite, is unknown.

In conclusion, the wildflysch with blocks extends all over the Teggiolo zone. In all the visited localities it forms the top part of the sedimentary cover of the Antigorio nappe, be it below the Lebendun or the Sambuco thrust, but the nature of the blocks changes from place to place. Their detailed study appears today as one of the best potential source of information for unraveling the early kinematics of nappe emplacement.
5.3 An embryo-tectonic trough for the Pizzo Castello wildflysch

The relations of the P. Castello with the two other types of wildflysch are probably more complex than a simple lateral passage. Several hints suggest that the base of the P. Castello wildflysch is erosive and truncates both other wildflysches, as if it formed an independent last cycle in the sedimentary history of the Teggiolo zone. In this scenario, the P. Castello wildflysch would fill a submarine trough created by a combination of embryonic tectonic movements and erosion (Fig. 12). Collapse (gravity-driven but probably tectonically triggered) of the rear part of the Antigorio-Teggiolo domain into the trough would have filled it with an accumulation of slices and blocks, the smaller ones going farther than the larger (hence the lateral size gradient). According to this reconstitution, the trough was asymmetric, with a gentle external (NW) slope, and a steeper internal (SE) slope corresponding to the short limb of an asymmetric anticline. At some point the growth of the anticline would have destabilized this slope, provoking its collapse. On the external slope, erosion of the underlying layers would have reached Robièi, where it would have truncated the Tamier-Zött wildflysch which abruptly disappears there. All these processes are submarine: comparison with other North-Penninic basins suggests a water depth of several $\mathrm{km}$.

This scenario would explain why in a vertical column above Campo the wildflysch only contains marble blocks at its base and at its top, with a thick intermediate part devoid of blocks (Fig. 2). The basal blocks clearly mark the continuation of the Alpe Tamia-Campo wildflysch. This lower wildflysch would be surmounted here not by the Tamier-Zött, but by the distal equivalent of the P. Castello wildflysch, which would be only composed here of fine-grained sediments, its blocks being trapped in the bottom of the trough (Fig. 12). In other words, in this scenario the external slope of the trough would cut, from NW to SE, successively deeper levels of the Teggiolo calcschists: first the Tamier-Zött wildflysch at Robièi, then the Alpe Tamia-Campo wildflysch near Campo, finally the lower part of the calcschists at the 2100 altitude (approx. 684.300/141.750; cf. Sects. 3.4.1 and 3.4.4), thus reaching the top of the Antabia group. On the contrary the upper blocks form a nearly continuous chain of elongated marble slices from the P. Castello to Robièi (mapped on the Basodino sheet as a continuous band of Triassic, Burckhardt and Günthert 1957), immediately below the Sambuco thrust: they represent a last pulse of block sliding at the end of the filling of the trough. 
5.4 Extent of the Limiting South-Helvetic Rise (LSHR) and comparison with other Mid-Jurassic Alpine inter-basinal rises

We established that the Teggiolo zone belongs to the southern limiting rise of the main Helvetic Jurassic basin (see above Sects. 3.3.6 and 5.1). We will call this paleogeographic element the Limiting South-Helvetic Rise (LSHR), never forgetting that it is defined in Mid-Jurassic (Dogger) times. Its extent is probably larger than the presently observable part of the Antigorio nappe. What do we know about it?

We first note that on the European margin of the Alpine Tethys, the LSHR is only one of a number of inter-basinal rises that experienced similar evolutions during Jurassic times: uplift from Middle Liassic to Early Dogger, leading to emersion and erosion, followed during Late Dogger and Malm by a gradual subsidence, recorded by the onlap of progressively younger sediments on the eroded pre-MidJurassic layers. The best examples are, to the $\mathrm{W}$ and the $\mathrm{N}$, the Aiguilles Rouges and the Internal Mont-Blanc-Aar massifs, and to the $\mathrm{S}$ the Monte Leone and, above all, the large Briançonnais s.str. rise where the beginning of the subsidence (after an uplift of $>1 \mathrm{~km}$ ) coincides with the $166 \mathrm{Ma}$ age of the oldest known oceanic crust in the Alpine Tethys (Bill et al. 1997). In all these examples we note that:

1. The width of the emergent territories must have been considerably greater than revealed by direct observation. They included on their rear large areas that have been dragged to depth by Alpine tectonics and are now hidden below nappes of more internal origin. This statement looks obvious in the light of modern tectonic cross-sections of the Alps (e.g. Escher et al. 1993) and is sometimes attested to by isolated slices, detached and transported to more external zones, where they are usually embedded in a wildflysch.

2. The time range of the progressive marine transgression on the eroded substratum covers the whole Late Dogger. Drowning of the emerged islands is usually not achieved before the beginning of Malm (Oxfordian). The resulting stratigraphic gap, where the Malm directly rests on the Triassic or sometimes even on the Paleozoic, is observed at best on the Aiguilles Rouges (e.g. Badoux et al. 1971) and in the internal parts of the Briançonnais (Siviez-Mischabel nappe, e.g. Sartori 1990; Acceglio zone in the French Alps, e.g. Lemoine 1961; and detached slices in the Prealps, e.g. Hürlimann et al. 1996).

The point is that the situation is identical in the LSHR. The composite blocks and slices of the Pizzo Castello wildflysch bring critical evidence. While in the directly observable part of the Teggiolo zone the Dogger transgression is materialized by the intercalation of the Sevinèra sandstone between the basement and the Malm marble, the P. Castello blocks show either the same threefold stratigraphy or a simpler two-fold sequence where the Dogger is missing and the Malm directly overlies the gneissic basement. This means that the shore of the Dogger LSHR island was situated in the territory that provided the P. Castello blocks, a territory that must have remained partially emergent until the beginning of the Malm. We already proposed this territory to be the back part of the Antigorio nappe (see above Sect. 5.2). The present discussion is consistent with this proposition.

Moreover, the hypothetical Tamia territory (cf. Sect. 5.2), that provided first the marble blocks of the Alpe Tamia-Campo wildflysch, then the gneiss blocks of the Tamier-Zött wildflysch, is also characterized by the direct superposition of the Malm marble upon the Paleozoic basement (blocks of another age being very rare or absent in these two wildflysches). Consequently this territory must also have remained emergent during the whole Dogger and was only covered by the sea at the beginning of the Malm. This paleogeographic reconstitution is in good agreement with the proposition (cf. Sect. 5.2) that this territory was situated between the Antigorio and Sambuco nappes. It also belonged to the LSHR.

In conclusion, the Mid-Jurassic LSHR extended at least across the whole Antigorio domain and onto the Tamia territory. When subsidence started, its higher part resisted the marine transgression until the end of Dogger: this more elevated sector corresponds to the rear of Antigorio and to the Tamia land. We note a remarkable analogy between the evolution of the LSHR and the other inter-basinal highs of the Alpine Jurassic paleogeography.

Work in progress suggests that the Mid-Jurassic paleoposition of the Sambuco nappe was out of the LSHR, on its southern slope towards a deep basin whose sedimentary (and partly volcanic) filling is to be found in the Lebendun and Pizzo del Vallone nappes. South of this basin, the Monte Leone formed a new high: it is more poorly known but continental deposits trapped in paleokarsts attest to its partial Mid-Jurassic emersion (Carrupt 2003). The Briançonnais s.str. rise was situated much father $\mathrm{S}$, beyond basins whose basement has largely disappeared by subduction but whose existence is revealed by significant portions of sedimentary cover detached and accumulated onto the external border of the Penninic Alps (e.g. Sion-Courmayeur) or even father $\mathrm{N}$ in the Prealps and the Central Swiss klippes (e.g. Gurnigel-Schlieren and Niesen nappes).

The uplift of all these paleogeographic thresholds is the counterpart of the deepening of the basins that separated them. These basins are filled by often thick, more or less turbiditic sediments fed by the erosion of the emerged territories, their bordering platforms and the collapse of 
submarine fault scarps. Recent research on continental margins provides realistic models of the simultaneous opening of several basins separated by faulted blocks on wide (several $100 \mathrm{~km}$ ) bands of highly extended continental crust (e.g. Manatschal et al. 2007; Péron-Pinvidic and Manatschal 2009; Jammes et al. 2009). According to these models a pre-breakup phase of extreme extension of the continental lithosphere controls the subsidence and may even lead to the local exhumation of windows of subcontinental mantle. These models give good explanations of the observations made on the European margin of the Alpine Tethys (Mohn et al. 2010), and particularly in the North-Penninic domain. In the Helvetic segment of the margin, where the basins were never extremely deep, extension was modest and the crust remained relatively thick. On the contrary, in the Penninic segment, much stronger Mid-Jurassic extension resulted in deeper basins, locally with basaltic volcanism (the Sabbione metabasites of the P. Vallone nappe, Carrupt 2003, and maybe the mysterious amphibolite blocks of the P. Bronzo wildflysch, see above Sect. 5.2), and in the exhumation of several windows of subcontinental mantle, such as the large Geisspfad ultramafic body (e.g. Pastorelli et al. 1995) and maybe the ultramafic lenses of the Isorno zone (Wieland 1966). A more detailed discussion of Alpine Mid-Jurassic geodynamics is beyond the scope of this paper. Here we only want to underline the critical role of the LSHR, of which the Antigorio-Teggiolo domain is the directly observable part, as a limit (and a link) between these two contrasted segments of the European margin.

\subsection{Pre-nappe folding}

The discovery of the Vanzèla fold and its possible correlation with the Valdo-Kalberhorn gneissic core have a theoretical interest that goes beyond the details of local geology. First we note that the Vanzèla fold was totally unsuspected before the new stratigraphic framework presented in this paper. The same is true for the corresponding large fold in the Teggiolo zone at the SE foot of the Basodino. Only the Kalberhorn fold, easily visible from the trace of the cover/basement interface, was known, but it was not understood in relation to the nappe tectonics.

It is known since long ago that the frontal hinge of the Antigorio nappe and its axial plane schistosity refold an older schistosity (Milnes 1964; Steck 1984). The latter author called these structures S2 and S1 respectively and he also established that the axial plane schistosity, which is a $\mathrm{S} 2$ in the gneissic core of the Antigorio nappe, becomes an S3 in the Lebendun nappe (Steck 2008). Our observations show that it is already an $\mathrm{S} 3$ in the sedimentary cover of the Antigorio nappe. This is the reason why we number F3 the Antigorio frontal fold and S3 its axial plane schistosity. It is probable that the $\mathrm{S} 1$ structure in the basement corresponds to both our S1 and S2 in the cover. Thus a single structure in the gneissic basement would correspond to two superimposed structures in its sedimentary cover. We suggest that this could result from the greater ductility of the sediments that allows a greater component of rotational strain during progressive deformation, favoring an early refolding of the first structures.

The point is that the analysis of the small structures reveals an important component of deformation in the Antigorio tectonic unit before the amplification of its frontal fold. If we classically consider that the large Antigorio recumbent fold (Gerlach 1869) is the "nappe I" of the Penninic pile (Argand 1911), these old deformations are, strictly speaking, pre-nappe (even if it might be hypothesized that they only represent early stages of a continuous process that culminated in the final nappe emplacement). Similar situations are known in other Penninic nappes (e.g. Monte Leone and Siviez-Mischabel). And every time the question arises: are there somewhere (in the same nappe) large folds that correspond to these early, omnipresent and penetrative, small structures? In the Antigorio nappe, the Vanzèla fold gives an answer: it presents a spectacular example of a $\mathrm{km}$-wide fold that is older than the frontal hinge of the nappe to which it belongs. This example might be significant in view of better understanding the kinematics of the Penninic nappes in general.

\subsection{Pre- to syn-wildflysch folding}

The existence of "pre-block" $F(-1)$ folds in the Robiè wildflysch is worth a more detailed comment. It underlines the difficulty to establish a unified system of structural chronology applicable to several distinct nappes or parts of the same nappe (see above Sect. 4.4). But the problem is even more complex in the light of recent studies in other regions of the Alps, which reveal that the wildflysch formation in a closing sedimentary basin (cf. Sect. 5.2) often takes place during the beginning of folding in this very basin (and not only in the neighboring domain that provided the blocks). The wildflysch is a syntectonic sediment in a very strict sense. This means that the "pre-block" folds observed in the Robièi wildflysch could be synchronous with very early folding in the same part of the Teggiolo domain, but not with the present-day $\mathrm{F} 1$ folds since the locally observable remnants of their S1 schistosity reveals physical conditions that already imply a certain degree of burial. The F(-1) folds of the blocks could be contemporaneous with an embryonic stage of our D1 deformation, or with another, more ancient folding not yet detected in the Antigorio nappe. As in many parts of the Alps, the so-called "D1" deformation might group collectively a number of distinct tectonic events that are not easily distinguishable. 
5.7 Mesozoic sediments do not "separate" the nappes

We take this occasion to correct a fundamental mistake, inherited from the early 20th century and which still appears in modern publications, according to which the zones of Mesozoic metasediments "separate" the nappes. In the Alps, and particularly in the Penninic, three possibilities exist: (1) a nappe can be formed mainly or totally by a detached sedimentary cover; (2) much more rarely it is formed by a denuded basement alone; (3) but the general rule is that the sedimentary covers are integral parts of nappes which are principally made of basement. In this case the transgressive contact of the sedimentary cover upon the basement is essentially a passive marker of the internal geometry of the nappe. This case is exemplified by the Teggiolo zone, which is simply the stratigraphically younger part of the Antigorio nappe.

We do not dispute that in practice, notably at the map scale, these bands of Mesozoic sediments are often very useful to help localizing the nappe boundaries. But it would be wrong to systematically draw thrusts along the cover/ basement contacts, as has too often been the case in the past.

\subsection{Non-existence of a "Teggiolo-Mulde"}

Another traditional error, more specific to the Lepontine Alps, is the concept of the "Teggiolo-Mulde" (Teggiolo syncline), which means that the Teggiolo zone would be a fold, with an axial trace running more or less in its middle until it would reach a hinge connecting the under- and overlying basements. It is understandable that, in the absence of any detailed stratigraphy, the older authors conferred a synclinal value to the bands of Mesozoic sediments intercalated between different basements, and indeed modern research in the Penninic nappes sometimes confirms that these bands are large recumbent folds (e.g. the St-Niklaus syncline in Valais that is a true, perfectly isoclinal fold connecting the Stalden zone with the SiviezMischabel nappe, Genier et al. 2008). But this is not the case of the Teggiolo zone. At all the localities we have investigated, stratigraphic analysis reveals that the Teggiolo zone is a fundamentally normal sedimentary cover that entirely belongs to the Antigorio nappe and whose youngest layers are directly overlaid by the thrust either of the Sambuco or of the Lebendun nappe.

\subsection{Completeness of the Antigorio nappe}

The Teggiolo zone always ends with the Robièi wildflysch, not only in the Val Bavona, but also along its SW continuation on at least $40 \mathrm{~km}$ until the Gondoschlucht and on the crest between the Val Antigorio and the Val Isorno (see above Sect. 5.2). In the Alps a wildflysch is always the youngest unit of a stratigraphic sequence. Consequently it is improbable that still younger layers have ever been deposited in the Teggiolo basin. In other words the Antigorio nappe is tectonically complete, no part of it has been sheared off to generate an independent nappe during Alpine tectonics.

Compared to the numerous cases where important portions of Alpine stratigraphic columns have been separated by intense shearing along a décollement horizon and are to be found today as independent nappes in more external parts of the belt (e.g. the Wildhorn nappe or the Prealps), this autochthonous destiny of the Teggiolo sediments (with respect to their Paleozoic basement) is worth an explanation. In all the Helvetic Alps, the main décollement horizon is the black shale formation of Aalenian (Early Dogger) age (Masson et al. 1980). According to our stratigraphic interpretation, this layer is missing in the Antigorio nappe because of the emersion of the Antigorio domain during Late Liassic to Early Dogger times. This situation is similar to other Mid-Jurassic rises of the Helvetic realm (e.g. the Aiguilles Rouges) where the sedimentary cover also remained more or less autochthonous.

\section{Conclusion}

The Teggiolo zone has a complex geological history, comprised of several sedimentary cycles separated by large stratigraphic gaps. According to our interpretation, based on the analysis of these discontinuities and on comparisons with classical stratigraphic sections in several well-known domains of the Alps, it covers the whole time span from Triassic to Eocene. Its lower part (Triassic-Jurassic-Lower Cretaceous) presents striking similarities with the interbasinal rises of the Helvetic realm (e.g. Internal MontBlanc), while its upper part (Upper Cretaceous to Tertiary) typically belongs to the North-Penninic (Valais s.l.) domain. Thus the Antigorio nappe occupies a crucial position in the paleogeographic restoration of the Alps, on the boundary between the Helvetic and Penninic realms. During Mid-Jurassic times, the Antigorio-Teggiolo domain was part of the Limiting South-Helvetic Rise (LSHR), which can be interpreted, in the light of recent works on continental margins, as a large faulted block, uplifted and partially emergent. This block played the role of a hinge between two segments of the Paleo-European margin which were submitted to contrasted evolutions: one whose basins subsided on moderately extended crust (the Helvetic); and one whose deeper basins were floored by hyperextended continental crust with exhumed mantle windows (the North-Penninic). At the end of Cretaceous times, the onset of subduction in this part of the Alps 
generated "flyschoid" sediments (the Valais s.l. series) that not only filled the North-Penninic basins, but spread towards the north over the limiting rise into the most internal parts of the Helvetic. This sedimentary evolution is exemplified by the Teggiolo calcschists.

An unexpected result of our work is the discovery of the important role played by complex formations of wildflysch type. The concept of wildflysch is central to Alpine geology. Our study shows that it is not restricted to the external parts of the belt but that it also exists, with all its essential characteristics, in the highly metamorphic Lepontine Alps. It may sound paradoxical but the excellent quality of the outcrops, due to the higher altitude and also to the metamorphic hardening of the rocks, can provide the opportunity for a more thorough insight into the complex internal structure of a wildflysch and its origin, indeed better than in the Prealps or in the Central Swiss klippes, where the usually very poor outcrop conditions of these soft formations constitute a major obstacle to their study.

In the Val Bavona, three different types of wildflysch are distinguished according to the nature of their blocks. They seem to fill troughs eroding down to various depths in the older layers of the Teggiolo zone. It is practical to group them into a stratigraphic unit called the Robièi Formation, at the top of the Teggiolo zone. The detailed investigation of their blocks: (1) gives clues to the existence and composition of source territories that have disappeared from the present-day level of observation, and (2) imposes constraints on the kinematics of early folding and embryonic nappe emplacement. A remarkable observation is the existence of "pre-block" F(-1) folds that are probably the oldest Alpine folds known in this part of the Alps.

Tectonic deformation of the Antigorio nappe produced several phases of superimposed folds and schistosities, more in the Teggiolo metasediments than in the gneissic basement. Rheological contrast explains this difference. The most striking point is the importance of older deformation that predates the amplification of the frontal hinge of the nappe. It created the usually dominant schistosity, at least two generations of superimposed small folds (F1 and $\mathrm{F} 2$ ), and a $\mathrm{km}$-wide isoclinal fold revealed by detailed mapping of the slopes above Vanzèla ( $\mathrm{N}$ of Campo). This fold corresponds to a similar structure, also revealed by detailed mapping based on our new stratigraphic framework in the Val Antabia at the SE foot of the Basodino peak. The gneissic core of this Vanzèla anticline is probably exposed on the Italo-Swiss boundary (Kalberhorn) and in the Toce valley (above Valdo). The frontal fold of the Antigorio nappe is younger and is consequently numbered F3.

Fundamentally the Teggiolo metasediments form an essentially normal, complete stratigraphic series that entirely belongs to the Antigorio nappe. Its completeness results from the absence of the highly ductile horizons that caused the décollement of large portions of the sedimentary series in many other domains of the Alps. This absence is itself the consequence of the Mid-Jurassic emersion of this critical paleogeographic rise. Once more tectonic evolution appears linked to stratigraphic evolution. Our hope is that these observations and their conclusions will help to gain a deeper insight into the evolution of the Paleo-European continental margin and on the kinematics of the Lower Penninic nappes in the Central Alps.

Acknowledgments We would like to thank all the participants to the 2009 field trip of the Swiss Tectonic Studies Group (N. Mancktelow, Zürich) who received a draft of a first version of this paper. The awful weather during the visit of the Robièi area did not prevent extremely stimulating discussions. We are particularly grateful to A. Steck (Lausanne) for detailed comments and suggestions in the field and at the Institute. One of us (H.M.) is deeply indebted to G. Martinotti (Torino) who introduced him many years ago to the geology of the Teggiolo zone during memorable excursions in the Antigorio valley. We thank D. Bussien, F. Bussy, R. Carreras, F. Della Torre and C. Jequier (Lausanne) for all the days spent together in the Val Bavona and Val Antabia and for fruitful discussions. We address our warmest thanks to G. Manatschal (Strasbourg) and N. Mancktelow (Zürich) for their very careful reviews of our manuscript and for their constructive remarks, and to A.G. Milnes (Corcelles) for interesting comments and for providing unpublished documents. We also thank the Museo Cantonale di Storia Naturale at Lugano for authorization to collect samples in Ticino and the direction of the hydroelectric plants of the Maggia (OFIMA SA) for transport by cable-car to Alpe di Sevinèra. This article is based on the Master's thesis of Battista Matasci who received the Swiss Geological Society Award for an outstanding master in Earth Sciences for the year 2009.

\section{References}

Ackermann, A. (1986). Le Flysch de la nappe du Niesen. Eclogae Geologicae Helvetiae, 79(3), 641-684.

Allaz, J. (2008). Metamorphic evolution in the northern Central Alps: Linking ${ }^{39} \mathrm{Ar}-{ }^{40} \mathrm{Ar}$ dating with thermobarometry (208 p.). Dissertation Universität Bern.

Anatra, S. (1986). Les faciès pélagiques de l'Ultrahelvétique entre Arve et Simme (206 p.). Thèse Université de Fribourg.

Antoine, P. (1971). La zone des Brèches de Tarentaise entre BourgSt-Maurice (Vallée de l'Isère) et la frontière italo-suisse. In Travaux du Laboratoire de Géologie de l'Université de Grenoble, Mémoires (Vol. 9, 367 p.).

Argand, E. (1911). Les nappes de recouvrement des Alpes Pennines et leurs prolongements structuraux. Matériaux pour la Carte géologique de la Suisse [N.S.] (Vol. 31/1).

Badoux, H., Burri, M., Gabus, J. H., Krummenacher, D., Loup, G., \& Sublet, P. (1971). Feuille 1305 Dt de Morcles. In Atlas géologique de la Suisse 1:25 000 (Vol. 58). Commission géologique Suisse.

Badoux, H., \& Homewood, P. (1978). Le soubassement de la nappe du Niesen dans la région du Sépey (Alpes vaudoises). In Bulletin du Laboratoire de Géologie de l'Université de Lausanne, 228, et Bulletin de la Société vaudoise des Sciences naturelles (Vol. $74 / 1$, p. 15-23).

Baud, A. (1987). Stratigraphie et sédimentologie des calcaires de Saint-Triphon (Trias, Préalpes, Suisse et France). Mémoires de Géologie (Lausanne) 1, 322. 
Baud, A., \& Mégard-Galli, J. (1975). Evolution d'un bassin carbonaté du domaine alpin durant la phase pré-océanique: cycles et séquences dans le Trias de la zone briançonnaise des Alpes occidentales et des Préalpes. In 9e Congrès international de Sédimentologie (Nice) (Vol. 5, p. 45-50).

Berger, A., \& Mercolli, I. (2006). Tectonic and Petrographic map of the Central Lepontine Alps 1:100 000 (Map sheet 43 Sopra Ceneri). In Carta geologica speciale (Vol. 127). Bern: Swisstopo.

Berger, A., Mercolli, I., \& Engi, M. (2007). Tectonic and petrographic map of the Central Lepontine Alps 1:100 000, Explanatory notes. In Carta geologica speciale (Vol. 127, 38 p.). Bern: Swisstopo.

Bergomi, M. A., Tunesi, A., Shi, Y.-R., Colombo, A., \& Liu, D.-Y. (2007). SHRIMP II U/Pb geochronological constraints of preAlpine magmatism in the Lower Penninic Units of the Ossola Valley (Western Alps, Italy). Geophysical Research Abstracts, 9, 07780.

Bill, M., Bussy, F., Cosca, M., Masson, H., \& Hunziker, J. C. (1997). High-precision $\mathrm{U}-\mathrm{Pb}$ and ${ }^{40} \mathrm{Ar} /{ }^{39} \mathrm{Ar}$ dating of an Alpine ophiolite (Gets nappe, French Alps). Eclogae Geologicae Helvetiae, 90(1), 43-54.

Bugnon, P.-C. (1986). Géologie de l'Helvétique à l'extrémité SudOuest du massif de l'Aar (Loèche, Valais) (106 p.). Thèse Université de Lausanne.

Burckhardt, C. E. (1942). Geologie und Petrographie des BasodinoGebietes (nordwestliches Tessin). Schweizerische Mineralogische und Petrographische Mitteilungen, 22(1), 99-188.

Burckhardt, C.E., \& Günthert, A. (1957). Blatt Basodino. Geologischer Atlas der Schweiz 1:25 000 (Vol. 34). Schweizerische Geologische Kommission.

Busnardo, R., Charollais, J., Weidmann, M., \& Clavel, B. (2003). Le Crétacé inférieur de la Veveyse de Châtel (Ultrahelvétique des Préalpes externes; canton de Fribourg, Suisse). Revue de Paléobiologie, Genève, 22(1), 1-174.

Bussien, D., Bussy, F., Magna, T., \& Masson, H. (2011). Timing of Paleozoic magmatism in the Maggia and Sambuco nappes and paleogeographic implications (Central Lepontine Alps). Swiss Journal of Geosciences, 104(1), 1-29.

Bussien, D., Bussy, F., Masson, H., Magna, T., \& Rodionov, N. (2008). Variscan lamprophyres in the Lower Penninic domain (Central Alps): age and tectonic significance. Bulletin de la Société Géologique de France, 179(4), 369-381.

Canepa, M. (1993). Evoluzione stratigrafica, tettonica e metamorfica di un settore di margine continentale al limite tra „Elvetico“ e „Pennidico“ : il caso delle unita „Pennidiche inferiori“ tra la Val Cairasca e la Val Formazza-Antigorio (provincia di Novara) (141 p.). Dottorato di Ricerca in Scienze della Terra, Università di Torino.

Caron, C. (1966). Sédimentation et tectonique dans les Préalpes: "flysch à lentilles" et autres complexes chaotiques. Eclogae Geologicae Helvetiae, 59(2), 950-967.

Caron, C., Homewood, P., \& Wildi, W. (1989). The original Swiss flysch: A reappraisal of the type deposits in the Swiss Prealps. Earth Science Reviews, 26, 1-45.

Carreras, R., \& Jequier, C. (2002). Etude géologique de la zone du Teggiolo au sud du Basodino (95 p.). Diplôme de Géologue, Université de Lausanne (unpubl.).

Carrupt, E. (2003). New stratigraphic, structural and geochemical data from the Val Formazza-Binntal area (Central Alps). Mémoires de Géologie (Lausanne), 41, 118.

Délèze, J.-Y. (1999). Géologie et minéralogie de la région de la Cristallina (Pennique inférieur, NW du Tessin) (288 p.). Diplôme de Géologue, Université de Lausanne (unpubl.).

Della Torre, F. (1995). Géologie et minéralogie du Pennique inférieur de la région de Robièi, Val Bavona (Tessin) (72 p.). Diplôme de Géologue, Université de Lausanne (unpubl.).
Elter, G., \& Elter, P. (1965). Carta geologica della regione del Piccolo S. Bernardo (Vol. 25, p. 1-53). Memorie degli Istituti di Geologia e Mineralogia dell' Università di Padova.

Epard, J.-L. (1989). Stratigraphie du Trias et du Lias dauphinois entre Belledonne, Aiguilles-Rouges et Mont-Blanc. Bulletin de Géologie (Lausanne), 304, et Bulletin de la Société vaudoise des Sciences naturelles, 79/4, 301-338.

Escher, A., Masson, H., \& Steck, A. (1993). Nappe geometry in the Western Swiss Alps. Journal of Structural Geology, 15, 501-509.

Favey, S. (1999). Géologie et minéralogie du Val Vannino (185 p.). Diplôme de Géologue, Université de Lausanne (unpubl.).

Frey, M. (1968). Quartenschiefer, Equisetenschiefer und germanischer Keuper-ein lithostratigraphischer vergleich. Eclogae Geologicae Helvetiae, 61(1), 141-156.

Galli, A., Mancktelow, N., Reusser, E., \& Caddick, M. (2007). Structural geology and petrography of the Naret region (northern Valle Maggia, N. Ticino, Switzerland). Swiss Journal of Geosciences, 100(1), 53-70.

Galster, F., Epard, J.-L., \& Masson, H. (2010). The Soja and LuzzoneTerri nappes: Discovery of a Briançonnais element below the front of the Adula nappe (NE Ticino, Central Alps). Bulletin de la Société vaudoise des Sciences naturelles, 92, 61-75.

Genier, F., Epard, J.-L., Bussy, F., \& Magna, T. (2008). Lithostratigraphy and $\mathrm{U}-\mathrm{Pb}$ zircon dating in the overturned limb of the Siviez-Mischabel nappe : a new key for Middle Penninic nappe geometry. Swiss Journal of Geosciences, 101(2), 431-452.

Gerlach, H. (1869). Die Penninischen Alpen. Neue Denkschriften der Schweizerischen Naturforschenden Gesellschaft, 23, 132.

Gisler, C., Hochuli, P. A., Ramseyer, K., Bläsi, H., \& Schlunegger, F. (2007). Sedimentological and palynological constraints on the basal Triassic sequence in Central Switzerland. Swiss Journal of Geosciences, 100(2), 263-272.

Grasmück, K. (1961). Die helvetischen Sedimente am Nordostrand des Mont Blanc-Massivs. Eclogae Geologicae Helvetiae, 54(2), $351-450$.

Greco, A. (1985). Analisi strutturale della parte frontale del ricoprimento pennidico dell'Antigorio in Val Formazza (Novara, Italia). Bolletino svizzero di Mineralogia e Petrografia, 65(2-3), 299-323.

Grujic, D., \& Mancktelow, N. S. (1996). Structure of the northern Maggia and Lebendun Nappes, Central Alps, Switzerland. Eclogae Geologicae Helvetiae, 89(1), 461-504.

Günthert, A. (1954). Beiträge zur Petrrographie und Geologie des Maggia-Lappens (NW-Tessin). Schweizerische Mineralogische und Petrographische Mitteilungen, 34(1), 1-159.

Günthert, A. (1958). Blatt Basodino, Erläuterungen. In Geologischer Atlas der Schweiz, 1:25000 (Vol. 34, 50 p.). Schweizerische Geologische Kommission.

Günthert, A., Stern, W., \& Schwander, H. (1996). The polycyclic evolution of the Penninic Maggia nappe, Central Alps: A summary report. Schweizerische Mineralogische und Petrographische Mitteilungen, 76(1), 1-22.

Huber, M. I. (1981). Geologisch-strukturelle Untersuchungen im oberen Maggiagebiet (Tessin, Schweiz) (221 p.). Dissertation ETH Zürich.

Huber, M., Ramsay, J., \& Simpson, C. (1980). Deformation in the Maggia and Antigorio nappes, Lepontine Alps. Eclogae Geologicae Helvetiae, 73(2), 593-606.

Hürlimann, A., Besson-Hürlimann, A., \& Masson, H. (1996). Stratigraphie et tectonique de la partie orientale de l'écaille de la Gummfluh (Domaine Briançonnais des Préalpes). Mémoires de Géologie (Lausanne), 28, 1-132.

Jammes, S., Manatschal, G., Lavier, L., \& Masini, E. (2009). Tectonosedimentary evolution related to extreme crustal thinnig 
ahead of a propagating ocean: Example of the western Pyrenees. Tectonics, 28, TC4012.

Joos, M. G. (1969). Zur Geologie und Petrographie der Monte GioveGebirgsgruppe im östlichen Simplon-Gebiet (Novara, Italia). Schweizerische Mineralogische und Petrographische Mitteilungen, 49(2), 277-323.

Keller, F., Wenk, E., Bianconi, F., \& Hasler, P. (1980). Foglio 1272 P. Campo Tencia. In Atlante geologico della Svizzera 1: 25000 (Vol. 73). Commissione Geologica Svizzera.

Kindler, P. (1988). Géologie des wildflyschs entre Arve et Giffre (Haute-Savoie, France) (Vol. 6, 134 p.). Publications du Département de Géologie et de Paléontologie de l'Université de Genève.

Kugler, C. (1987). Die Wildegg-Formation im Ostjura und die SchiltFormation im östlichen Helvetikum; ein Vergleich. Mitteilungen aus dem Geologischen Institut der ETH und der Universität Zürich, 159, 209.

Lemoine, M. (1961). La marge externe de la fosse piémontaise dans les Alpes occidentales. Revue de Géographie Physique et de Géologie Dynamique, 4/3(2), 163-180.

Lempicka-Münch, A. (1996). La géologie de la Zone des Cols de l'Oberland bernois entre Geils (Adelboden) et la Sarine (145 p.). Thèse Université de Lausanne.

Leu, W. (1986). Lithostratigraphie und Tektonik der nordpenninischen Sedimente in der Region Bedretto-Baceno-Visp. Eclogae Geologicae Helvetiae, 79(3), 769-824.

Lodetti, F. (2001). Géologie et minéralogie de la région du Naret (Pennique inférieur, NW du Tessin) (173 p.). DEA Sciences de la Terre, Université de Lausanne (unpubl.).

Maggini, L. (1999). Sur le pli du Wandfluhhorn dans la région du Lago Matogno, Valle dell'Isorno (Italie) (124 p.). Diplôme de Géologue, Université de Lausanne (unpubl.).

Manatschal, G., Müntener, O., Lavier, L.L., Minshull, T.A., \& PéronPinvidic, G. (2007). Observations from the Alpine Tethys and Iberia-Newfoudland margins pertinent to the interpretation of continental breakup. In G.D. Karner, G. Manatschal \& L.M. Pinhero (Eds.), Imaging, mapping and modelling continental lithosphere extension and breakup. Geological Society of London Special Publications, 282, 291-324.

Masson, H. (2002). Ophiolites and other (ultra)basic rocks from the West-Central Alps: New data for a puzzle. Bulletin de la Société vaudoise des Sciences naturelles, 88(2), 263-276.

Masson, H., Bussy, F., Eichenberger, M., Giroud, N., Meilhac, C., \& Presniakov, S. (2008). Early Carboniferous age of the Versoyen ophiolites and consequences: Non-existence of a «Valais ocean» (Lower Penninic, western Alps). Bulletin de la Société géologique de France, 179(4), 337-355.

Masson, H., Herb, R., \& Steck, A. (1980). Helvetic Alps of Western Switzerland. In Schweizerische Geologische Kommission (Ed.), Geology of Switzerland, a guide-book, Pt. B: Geological excursions (p. 109-153). Basel: Wepf.

Maxelon, M., \& Mancktelow, N. S. (2005). Three-dimensional geometry and tectonostratigraphy of the Pennine zone, Central Alps, Switzerland and Northern Italy. Earth Science Reviews, 71, 171-227.

Mégard-Galli, J., \& Baud, A. (1977). Le Trias moyen et supérieur des Alpes nord-occidentales et occidentales: données nouvelles et corrélations stratigraphiques. Bulletin du BRGM, IV/3(2), 233-250.

Milnes, A.G. (1964). Structure and history of the Antigorio nappe (Simplon group, North Italy) (86 p.). Ph.D. Dissertation Universität Basel.

Milnes, A. G. (1965). Structure and history of the Antigorio nappe (Simplon group, North Italy). Schweizerische Mineralogische und Petrographische Mitteilungen, 45(1), 167-177.
Milnes, A. G. (1974). Post-nappe folding in the Western Lepontine Alps. Eclogae Geologicae Helvetiae, 67(2), 333-348.

Mohn, G., Manatschal, G., Müntener, O., Beltrando, M., \& Masini, E. (2010). Unravelling the interaction between tectonic and sedimentary processes during lithospheric thinning in the Alpine tethys margins. International Journal of Earth Sciences, 99(Suppl. 1), 75-101.

Oberhänsli, R. (1986). Geochemistry of meta-lamprophyres from the Central Swiss Alps. Schweizerische Mineralogische und Petrographische Mitteilungen, 66(3), 315-342.

Ospina-Ostios, L.M., Ragusa, J., \& Kindler, P. (2010). New biostratigraphic data from the Voirons Sandstones (Voirons massif, Haute-Savoie, France): Implications for the paleogeographic origin of the Gurnigel Nappe. In 8th Swiss Geoscience Meeting, Fribourg, Abstract Volume (p 121-122).

Pastorelli, S., Martinotti, G., Piccardo, G.B., Rampone, E., \& Scambelluri, M. (1995). The Geisspfad complex and its relationships with the Monte Leone nappe (Lower Pennine, Western Alps). In R. Polino \& R. Sacchi (Eds.), Rapporti AlpiAppennino. Accademia Nazionale delle Scienze (Roma), Scritti e documenti (Vol. 14, p. 349-358).

Péron-Pinvidic, G., \& Manatschal, G. (2009). The final rifting evolution at deep magma-poor passive margins from IberiaNewfoundland: A new point of view. International Journal of Earth Sciences, 98(7), 1581-1597.

Preiswerk, H. (1912). Die Struktur der nördlichen Tessineralpen. Eclogae Geologicae Helvetiae, 12(2), 169-172.

Ramsay, J. G. (1967). Folding and fracturing of rocks (568 p.). New York: McGraw-Hill.

Ramsay, J. G., \& Allison, I. (1979). Structural analysis of shear zones in an alpinised Hercynian granite (Maggia Lappen, Pennine Zone, Central Alps). Schweizerische Mineralogische und Petrographische Mitteilungen, 59(3), 251-279.

Reinhard, M., \& Preiswerk, H. (1934). Excursion Nr. 65 CristallinaVal Bavona-Bignasco-Locarno. Geologischer Führer der Schweiz (Vol. XI, p. 819-823). Basel: Wepf.

Rodgers, J., \& Bearth, P. (1960). Zum Problem der Lebendundecke. Eclogae Geologicae Helvetiae, 53(1), 169-178.

Sartori, M. (1990). L'unité du Barrhorn (Zone pennique, Valais, Suisse). Mémoires de Géologie (Lausanne), 6, 1-156.

Schardt, H. (1903). Note sur le profil géologique et la tectonique du massif du Simplon (119 p.). Lausanne: Corbaz.

Schmidt, C. (1907). Ueber die Geologie des Simplongebietes und die Tektonik der Schweizeralpen. Eclogae Geologicae Helvetiae, 9(4), 484-584.

Schmidt, C., \& Preiswerk, H. (1908a). Geologische Karte der Simplon-Gruppe 1:50 000. Geologische Spezialkarte (Vol. 48). Schweizerische Geologische Kommission.

Schmidt, C., \& Preiswerk, H. (1908b). Erläuterungen zur geologischen Karte der Simplongruppe in 1: 50000 (72 p.). Geologische Kommission der Schweizerischen Naturforschenden Gesellschaft.

Spring, L., Reymond, B., Masson, H., \& Steck, A. (1992). La nappe du Lebendun entre Alte Kaserne et le Val Cairasca (massif du Simplon): nouvelles observations et interprétations. Eclogae Geologicae Helvetiae, 85(1), 85-104.

Steck, A. (1984). Structures de déformations tertiaires dans les Alpes centrales. Eclogae Geologicae Helvetiae, 77(1), 55-100.

Steck, A. (1998). The Maggia cross-fold: An enigmatic structure of the Lower Penninic nappes of the Lepontine Alps. Eclogae Geologicae Helvetiae, 91(3), 333-343.

Steck, A. (2008). Tectonics of the Simplon massif and Lepontine gneiss dome: deformation structures due to collision between the underthrusting European plate and the Adriatic indenter. Swiss Journal of Geosciences, 101(2), 515-546. 
Steck, A., Bigioggero, B., Dal Piaz, G.V., Escher, A., Martinotti, G., \& Masson, H. (1999). Carte tectonique des Alpes de Suisse occidentale et des régions avoisinantes 1: 100 000. In Carte géologique spéciale (Vol. 123). Bern: Service hydrologique et géologique national.

Steck, A., Epard, J.-L., Escher, A., Gouffon, Y., \& Masson, H. (2001). Carte tectonique des Alpes de Suisse occidentale et des régions avoisinantes 1: 100 000, Notice explicative. In: Carte géologique spéciale (Vol. 123, 73 p.). Bern: Office fédéral des eaux et de la géologie.

Steck, A., \& Hunziker, J. (1994). The Tertiary structural and thermal evolution of the Central Alps-Compressional and extensional structures in an orogenic belt. Tectonophysics, 238, 229-254.

Steiner, H. (1984). Mineralogisch-petrographische, geochemische und isotopengeologische Untersuchungen an einem Meta-Lamprophyr und seinem granodioritischen Nebengestein (MatorelloGneis) aus der Maggia-Decke. Schweizerische Mineralogische und Petrographische Mitteilungen, 64(1-2), 261-271.

Steinmann, M.C. (1994). Die nordpenninischen Bündnerschiefer der Zentralalpen Graubündens: Tektonik, Stratigraphie und Beckenentwicklung (220 p.). Dissertation ETH Zürich.

Trümpy, R. (1954). La zone de Sion-Courmayeur dans le haut Val Ferret valaisan. Eclogae Geologicae Helvetiae, 47(2), 315-359.

Trümpy, R. (1955). Remarques sur la corrélation des unités penniques externes entre la Savoie et le Valais et sur l'origine des nappes préalpines. Bulletin de la Société géologique de France, 5(6), 217-231.

Trümpy, R. (2006). Geologie der Iberger Klippen und ihrer FlyschUnterlage. Eclogae Geologicae Helvetiae, 99(1), 79-121.

van Stuijvenberg, J. (1979). Geology of the Gurnigel area (Prealps, Switzerland). Matériaux pour la Carte géologique de la Suisse [N.S.], 151, 111.

Weidmann, M., Homewood, P., Caron, C., \& Baud, A. (1976). Réhabilitation de la «Zone Submédiane» des Préalpes. Eclogae Geologicae Helvetiae, 69(2), 265-277.

Weidmann, M., Homewood, P., \& Fasel, J.-M. (1982). Sur les terrains subalpins et le Wildflysch entre Bulle et Montreux. Bulletin de la Société vaudoise des Sciences naturelles, 76(2), 151-183.

Wieland, H. (1966). Zur Geologie und Petrographie der Valle Isorno (Novara, Italia). Schweizerische Mineralogische und Petrographische Mitteilungen, 46(1), 189-303.

Winkler, W., Wildi, W., van Stuijvenberg, J., \& Caron, C. (1985). Wägital-Flysch et autres flyschs penniques en Suisse Centrale. Stratigraphie, sédimentologie et comparaisons. Eclogae Geologicae Helvetiae, 78(1), 1-22.

Wyss, R., \& Isler, A. (2007). Blatt 1234 Vals, Erläuterungen. Geologischer Atlas der Schweiz 1:25 000 (Vol. 121, 78 p.). Bern: Swisstopo. 